\title{
First insights into the structure and environmental setting of cold-seep communities in the Marmara Sea
}

\author{
Bénédicte Ritt ${ }^{a,{ }^{*}}$, Jozée Sarrazin ${ }^{a,{ }^{*}}$, Jean-Claude Caprais $^{a}$, Philippe Noël ${ }^{\mathbf{a}}$, Olivier Gauthier ${ }^{\mathbf{a}, \mathbf{b}}$, \\ Catherine Pierre $^{c}$, Pierre Henry ${ }^{d}$ and Daniel Desbruyères ${ }^{a}$
}

\author{
a Ifremer-Centre de Brest, DEEP/LEP, BP 70, 29280 Plouzané, France \\ ${ }^{\mathrm{b}}$ Université de Bretagne Occidentale, IUEM, LEMAR (UMR 6539), Technopôle Brest-Iroise, Place Nicolas \\ Copernic, 29280 Plouzané, France \\ ${ }^{c}$ Université Paris 06, LOCEAN (UMR 7159), F-75252 Paris 05, France \\ ${ }^{d}$ CEREGE, Chaire de géodynamique du Collège de France, Europôle de l'Arbois, BP 80, 13545 Aix-en-Provence \\ Cedex 04, France
}

*: Corresponding author : B. Ritt, J. Sarrazin : benedicte.ritt@ifremer.fr ; jozee.sarrazin@ifremer.fr

\begin{abstract}
:
A brackish-water cold seep on the North Anatolian Fault (NAF) in the Marmara Sea was investigated with the Nautile submersible during the MarNaut cruise in 2007. This active zone has already been surveyed and revealed evidence of active seeping on the seafloor, such as bubble emissions, patches of reduced sediments, microbial mats and authigenic carbonate crusts. MarNaut was the first opportunity to sample benthic communities in the three most common microhabitats (bioturbated and reduced sediments, carbonate crust) and to examine their relationships with environmental conditions. To do so, faunal communities were sampled and chemical measurements were taken close to the organisms. According to diversity indices, the bioturbated microhabitat exhibited the highest taxonomic diversity and evenness despite a lower number of samples. Conversely, the reduced sediment microhabitat exhibited the lowest taxonomic diversity and evenness. The carbonate crust microhabitat was intermediate although it had the highest biomass. Multivariate analyses showed that (1) fauna were relatively similar within a single microhabitat; (2) faunal community structure varied greatly between the different microhabitats; (3) there was a link between faunal distribution and the type of substratum; and (4) chemical gradients (i.e. methane, oxygen and probably sulphides) may influence faunal distribution. The estimated fluid flow velocity $(0.4-0.8 \mathrm{~m} / \mathrm{yr})$ confirmed the presence of fluid emission and provided evidence of seawater convection in the two soft-sediment microhabitats. Our results suggest that the reduced sediments may represent a harsher environment with high upward fluid flow, which restrains seawater from penetrating the sediments and inhibits sulphide production, whereas bioturbated sediments can be viewed as a bio-irrigated system with sulphide production occurring at greater depths. Therefore, the environmental conditions in reduced sediments appear to prevent the colonization of symbiont-bearing fauna, such as vesicomyid bivalves, which are more often found in bioturbated sediments. Fluid flow appears to control sulphide availability, which in turn influences the horizontal and vertical distribution patterns of fauna at small spatial scales as observed at other seep sites
\end{abstract}

Keywords: Marmara Sea; Cold seep; Benthic fauna; Biological diversity; Environmental conditions; Chemosynthetic. 
Cold-seep ecosystems are home to chemosynthetic communities composed of a number of endemic vesicomyid, solemyid and mytilid bivalves, as well as several siboglinid polychaetes that are often the dominant macro- and megafauna (Bergquist et al. 2003, 2005; Levin and Mendoza 2007; Levin et al. 2003; Luth et al. 1999; Olu et al. 1996, 1997; Olu-Le Roy et al. 2004, 2007; Paull et al. 1984; Sahling et al. 2002; Sibuet and Olu, 1998). One of the key adaptations of species to seep habitats is their association with bacterial endosymbionts, which ensure chemosynthetic primary production through the oxidation of the reduced compounds contained in the seeping fluids (Cavanaugh, 1983; Childress et al., 1986; Dubilier et al., 2008; Fisher, 1990). Thus, these taxa rely on seeping fluids for their nutrition and survival, and their spatial distribution is a reliable indicator of the presence of chemical fluxes at the sediment-water interface (Levin, 2005; Sibuet and Olu, 1998). Other heterotrophic species live in association with seep chemosynthetic species, benefiting from these enriched environments (Tunnicliffe et al., 2003) and also relying on organic inputs derived from neritic (coastal) and terrestrial organic material (Gage, 2003).

Recent studies on seep ecosystems have highlighted the vast heterogeneity of habitats and associated faunal assemblages at small spatial scales that range from the sampling unit (dm scale) to the geological structure ( $\mathrm{km}$ scale) on which the assemblages are found (Vanreusel et al., 2009). Although there are some similarities between structures and regions, each newly discovered seep area may have its own signature in terms of faunal structure, diversity and chemical conditions. Previous studies have suggested that the composition and intensity of fluid seepage are the major factors structuring the distribution of seep fauna (Levin, 2005; Sibuet and Olu, 1998). Other driving forces, such as depth (Sibuet and Olu, 1998), substratum type (Olu et al., 1996; Sahling et al., 2003), oxygen concentration (Bergquist et al., 2005; Levin and Gage, 1998), biological interactions (Bergquist et al., 2003) and hydrographic regime (Luth and Luth, 1998; Luth et al., 1999) have also been suggested to play a role on species distribution patterns.

Recently, the deep-sea sites of the Marmara Sea $\left(40-41^{\circ} \mathrm{N} ; 26-30^{\circ} \mathrm{W}\right)$ have received more attention from the scientific community, mainly because of the seismic hazard in the Istanbul area. This intra-continental sea, located on the North-Anatolian Fault 
zone (NAF), is tectonically active (Armijo et al., 2004; Le Pichon et al., 2001; Sengor et al., 2005). Submarine earthquakes constitute a potential threat for human populations (Ambraseys, 2000; Ambraseys and Finkel, 1991; Ansal et al., 2009; Hubert-Ferrari et al., 2000; Oglesby et al., 2008). These earthquakes influence gas emissions (Hovland et al., 2002) as confirmed by the presence of gas flares in the Izmit Gulf following the 1999 Kocaeli earthquake (Alpar, 1999). Subsequent investigations have revealed cold seeps in the deep basins of the Marmara Sea along the main fault, on secondary fault branches and on the anticline ridges (Armijo et al., 2005; Geli et al., 2008; Halbach et al., 2004; Zitter et al., 2008). The most common evidence for fluid expulsion in the Marmara Sea is the presence of black patches of reduced sediments associated with microbial mats and authigenic carbonate crusts (Zitter et al., 2008). While these generally correspond to zones of diffuse flow, focused flow of brackish water has been observed at two sites (Zitter et al., 2008). Moreover, cold seeps can release hydrocarbons as a separate gas phase, and even as oil (Bourry et al., 2009; Geli et al., 2008). Seeps can be thus characterised by gas flares, brackish-water springs or diffuse emission, depending on the dominant mode of fluid emission.

In 2007, the MarNaut cruise represented the first opportunity to sample the fauna associated with the cold-seep ecosystems of the Marmara Sea and to characterise the abiotic conditions of this basin of the eastern Mediterranean Sea. The present study aims to describe the structure of the benthic communities in the three most common microhabitats of a brackish-water cold seep and relate community structure to local environmental factors. Even though these objectives were hindered by sampling limitations, this study represents a fundamental step in advancing our understanding of the ecology and biogeography of chemosynthetic seep species within the larger Mediterranean context.

\section{Materials and methods}

\subsection{Study area}

Located between $40-41^{\circ} \mathrm{N}$ and $26-30^{\circ} \mathrm{W}$, the Marmara Sea is the easternmost semienclosed basin of the Mediterranean Sea, and connects the Black Sea to the Aegean Sea via the Bosphorus and Dardanelles Straits. It is subdivided into four major basins 
from east to west: the Çinarcik, Kumburgaz, Central and Tekirdağ basins, with a maximum depth of about $1260 \mathrm{~m}$ in the Central basin (Figure 1).

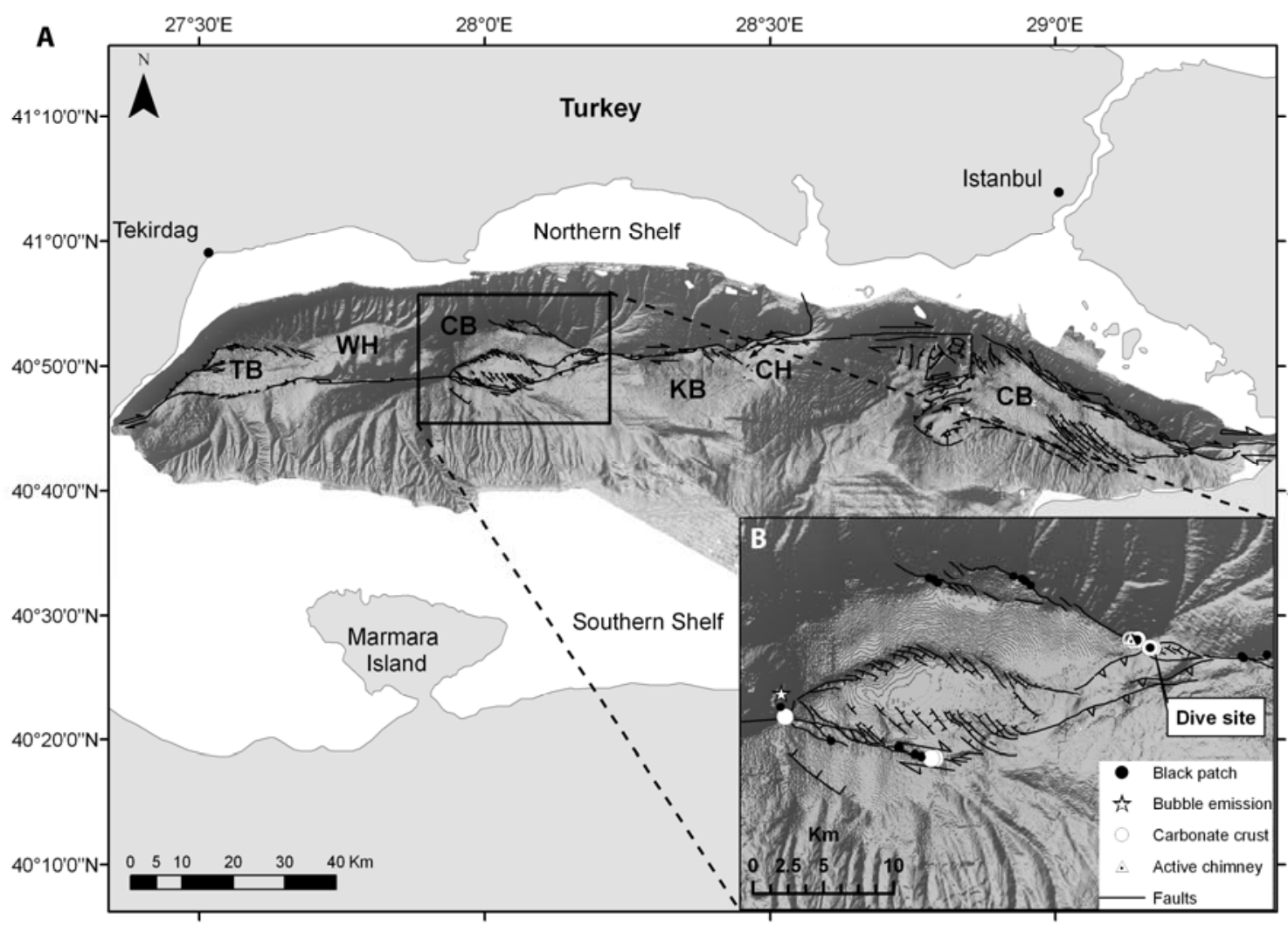

Fig. 1. (A) General bathymetric map of the Marmara Sea showing the fault traces (from Le Pichon et al., 2001), the different geological basins and (B) details of the study area in the Central Basin. The presence of black patches on the seafloor (black dots), carbonate crusts (white dots), active chimney (white triangle) and bubble emission (white star) were mapped according to the observations reported during the MARMARASCARPS cruise (Zitter et al., 2008) and exploratory MarNaut dives. The dive site corresponds to the site dedicated to environmental and faunal sampling during the MarNaut cruise in 2007. Abbreviations: TB, Tekirdağ Basin; CB, Central Basin; CB, Çinacik Basin; KB, Kumburgaz Basin; WH, Western High; $\mathrm{CH}$, Central High.

Preliminary visual observations of the Marmara Sea seafloor and the associated epibenthic communities were carried out using the ROV Victor 6000 during the MARMARASCARPS cruise in 2002 (Armijo et al., 2005; Zitter et al., 2008). Our observations and sampling were carried out five years later during the MarNaut cruise (2007) on the R/V L'Atalante with the manned submersible Nautile. During this cruise, exploratory dives were carried out to map seepage occurrences and faunal distributions at selected sites in the four major basins. Five sampling dives took place at the brackish-water spring described in this study. One of these dives was 
environmental features in the north-east Central basin $\left(40^{\circ} 51.27^{\prime} \mathrm{N}-28^{\circ} 10.19^{\prime} \mathrm{W}\right)$ at a depth of $1120 \mathrm{~m}$ (Figure 1).

\subsection{Sampling site}

The chosen seep site harboured a mosaic of microhabitats. Three of these were selected and sampled: (1) the bioturbated sediment microhabitat (Bio) was characterised by brown sediments with small bioturbation holes (Figure 2a); (2) large patches of reduced sediment microhabitat (Red) were covered by short polychaete tubes and were surrounded by Bio patches (Figure 2b); and, (3) sparse carbonate crusts were located a couple of meters from Red patches and collectively constitute the Carbonate Crust microhabitat (CC, Figure 2c).
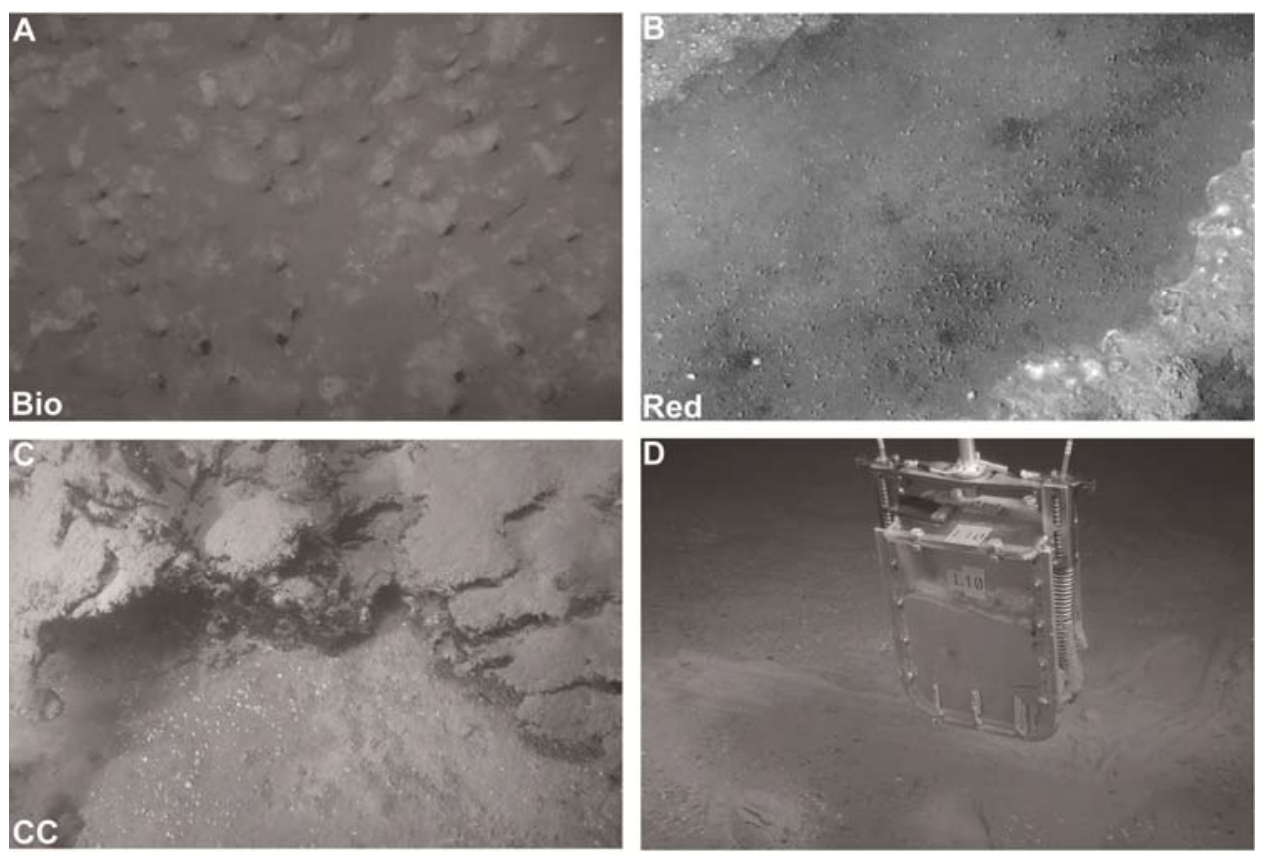

Fig. 2. Photographs of each of the three most common microhabitats of the Marmara cold seeps: (A, Bio) bioturbated sediments, $(B$, Red) reduced sediments and $(C, C C)$ carbonate crusts (MarNaut cruise, 2007). (D) blade corer used for sampling chemosynthetic communities with the submersible.

Environmental characterisation of each microhabitat was conducted before sampling fauna to avoid any disturbance that could be caused by this sampling. Temperature and salinity measurements were performed using the MicroCat autonomous sensor (F. Harmegnies, Ifremer). Mean values were computed after deploying the sensor for 1 min above the organisms and as close as possible to the seafloor using Nautile's manipulator arm. Water and sediment samples were then taken for chemical analyses using $200 \mathrm{ml}$ titanium bottles and tube corers (30 cm long; $5.4 \mathrm{~cm}$ inner 
diameter), respectively. Complete sampling details are given in Table 1.

Unfortunately, due to time constraints imposed by the use of a manned submersible, the physico-chemical sampling could not be completed above Bio and was not performed above CC. Sediments were also sampled with blade corers (Bayon et al., 2009; Menot et al., 2009, area:0.02m², Figure 2d) deployed by Nautile's arm to collect the epi- and endofauna. The number of samples for each microhabitat varied, depending on time and number of tools available (Table 1).

\subsection{Physico-chemical analyses}

The $200 \mathrm{ml}$ water samples were used to determine $\mathrm{pH}$ as well as methane concentrations. $\mathrm{pH}$ measurements were performed on board with a pH-meter connected to a glass electrode (Metreohm) and were corrected for ambient temperature $\left(25^{\circ} \mathrm{C}\right)$ and atmospheric pressure. Reproducibility of the method was $\pm 0.01 \mathrm{pH}$ units. Methane concentrations were measured in the laboratory using the headspace technique coupled with a gas chromatograph equipped with a flameionisation detector (error of 4\%, see details in Sarradin and Caprais, 1996).

Sediments from tube corers were split horizontally on board and pore water was extracted by centrifugation of the different sediment layers (every $\mathrm{cm}$ for the first 2 $\mathrm{cm}$ and every $2 \mathrm{~cm}$ until the end of the core) to measure chlorinity and sulphate concentrations with an ionic chromatograph on an isocratic system DX 120 (DIONEX). Intact cores, along with supernatant water, were used for oxygen measurements. Oxygen profiles within supernatant water and sediments were obtained by using a microsensor OX 100 coupled to a pico-ammeter 5PA 2000 (Unisense) and a micro-manipulator using the Profix data acquisition software (Unisense). The resolution of the sensor was $<200 \mu \mathrm{m}$. Kendall rank correlations $(\tau)$ (Kendall, 1938) were computed between chlorinity and sulphate profiles for the Red and Bio microhabitats.

\subsection{Carbonate mineralogy}

The mineralogy of the diagenetic carbonates was determined by $X$ ray diffraction. The oxygen and carbon isotopic compositions of carbonates have been measured to characterize the water and carbon sources of the fluids from which the carbonates have precipitated. They are expressed in the conventional $\delta$ notation defined as: 
$\delta=[(\mathrm{Rs} / \mathrm{Rr})-1]{ }^{*} 1000$, where $\mathrm{R}={ }^{18} \mathrm{O} /{ }^{16} \mathrm{O}$ or ${ }^{13} \mathrm{C} /{ }^{12} \mathrm{C}$ respectively in the sample (Rs) and in the reference (Rr). The reference for $\delta^{18} \mathrm{O}$ and $\delta^{13} \mathrm{C}$ is the V-PDB (Craig, 1957; Gonfiantini et al., 1995). The $\mathrm{CO}_{2}$ gas extracted from the carbonate by attack with $100 \%$ phosphoric acid at $90^{\circ} \mathrm{C}$ was analysed with a triple collector mass spectrometer (ISOPRIME). The analytical precision $2 \sigma$ is $0.01 \%$ for both $\delta^{18} \mathrm{O}$ and $\delta^{13} \mathrm{C}$; the reproducibility is $0.05 \%$ for $\delta^{18} \mathrm{O}$ and $\delta^{13} \mathrm{C}$.

\subsection{Estimation of fluid velocity in sediments}

Since fluid flow velocity influences the distribution of seep faunal assemblages, we have used models of geochemical gradients to estimate fluid flow for the different microhabitats. It is known that the transport of dissolved species such as chloride occurs both through molecular diffusion and advection of interstitial water. The magnitude of diffusive flux and the velocity of advective flow provide constraints for models that can be estimated from the observed chlorinity profiles, a conservative aqueous species. If a steady-state condition is assumed for approximate calculation of the flow velocity, the concentration of dissolved chloride can be described by a partial differential equation (Berner, 1974):

$D_{s}\left(d^{2} C / d x^{2}\right)+v(d C / d x)=0$

where $C$ is the concentration of dissolved chloride $(\mathrm{mmol} / \mathrm{l}), x$ is the absolute depth $(\mathrm{cm})$ measured downward from the sediment-water interface, $D_{s}$ is the diffusion coefficient of chloride in sediments ( $\mathrm{m}^{2} / \mathrm{yr}$ ), and $v$ is the absolute upward vertical velocity of interstitial water relative to the sediment-water interface $(\mathrm{m} / \mathrm{yr})$. The diffusion coefficient used here for this model was $0.036 \mathrm{~m}^{2} / \mathrm{yr}$ at $14^{\circ} \mathrm{C}$ for a porosity of $70 \%$ and a tortuosity factor of 1.4 (Henry et al., 1996; Li and Gregory, 1974). For all three tube cores, the chlorinity of seawater and of the emissions were assumed to be equal to $583 \mathrm{mmol} / \mathrm{l}$ and $496 \mathrm{mmol} / \mathrm{l}$, respectively. Average velocity was fitted to each core. The diffusion coefficient of sulphate in marine sediments is half that of chloride (Iversen and Jørgensen, 1993) and sulphate profiles that would result from the sole effect of diffusion and advection, without any sulphate reduction, were computed assuming a seawater sulphate concentration of $30 \mathrm{mmol} / \mathrm{l}$ and an incoming fluid concentration of $0 \mathrm{mmol} / \mathrm{l}$. 
2.6. Faunal sorting and identification

Sediments from blade corers dedicated to faunal sampling and sampled at Bio and

Red were photographed and split horizontally $(0-1,1-3,3-5,5-10,>10 \mathrm{~cm})$ immediately after recovery. Core slices were passed through a sieve column (2 $\mathrm{mm}$, $1 \mathrm{~mm}, 500 \mu \mathrm{m}, 250 \mu \mathrm{m}$ ) and the retained residues were preserved in 10\% buffered formalin. In the laboratory, all sediments were rinsed and invertebrates were sorted under a dissecting microscope and identified to the lowest taxonomic level possible. The CC samples were also washed over a $250 \mu \mathrm{m}$ mesh and the organisms retained were processed in the same way as those on the soft sediments. Due to space limitations on Nautile, two of the crust samples (CC1 and CC2) were put in the same sampling box. While the crusts themselves were treated separately, it was impossible to determine the origin of the material that had fallen to the bottom of the box. This was treated as a combined "sample" ( $\left.\mathrm{CC}_{\mathrm{box}}\right)$ that was only used when pooling all the carbonate crust data for $\alpha$-diversity analyses.

The surface of the sampled carbonate crusts was estimated using the IPLab Spectrum $\AA$ image analysis software. Quantitative 2-D surface analyses were performed on video images, three times for each frame to reduce error resulting from on-screen tracing (Sarrazin and Juniper, 1999). Total surface area was used to calculate area-related indicators, such as density and biomass. However, because it does not take topography into account, this method probably underestimates surface area and in turn overestimates density and biomass.

In this study, we considered macrofauna sensu stricto $(>250 \mu \mathrm{m}$, Hessler and Jumars 1974), so any meiofaunal taxa such as Nematoda, Copepoda and Ostracoda were considered separately. Nevertheless, the resulting meiofaunal list was very incomplete. Meiofauna sensu stricto were underestimated since only the fauna retained by a $250 \mu \mathrm{m}$ mesh was analysed instead of the $32 \mu \mathrm{m}$ to $62 \mu \mathrm{m}$ mesh size usually used for this faunal compartment (Hessler and Jumars, 1974; Thistle, 2003; Van Gaever et al., 2006). For most identified taxa, we achieved the family level except for Demospongia, Scyphozoa, Nematoda. While in the first two groups, only one morphology could be distinguished among the specimens, suggesting the presence of a single family, in the latest, several morphologies were identified. 
The mean wet weight ( $w w$ ) was measured for each microhabitat. To do so, individuals of all major macrofaunal taxa (bivalves, polychaetes, gastropods crustaceans) present in a sample were pooled, pat-dried on absorbent paper and weighed on a micro-scale balance with an error of $0.1 \mathrm{mg}$.

\subsection{Faunal diversity analyses}

\subsubsection{Alpha-diversity}

Alpha-diversity analyses were only performed for macrofauna and at the family level, with the exception of Demospongia and Scyphozoa. For meiofauna, only family richness for copepods, ostracods and mites is reported as a measure of alphadiversity. Rarefaction curves (sensu Gotelli and Colwell, 2001) were computed on macrofaunal data for each microhabitat. Rarefaction curves plot expected taxonomic richness against sampling effort (Gauthier et al., 2010; Gotelli and Colwell, 2001; Hurlbert, 1971) and helps in evaluating sampling adequacy in different groups of samples. Because of the single sample from Bio, individual-based rarefaction was used in all microhabitats although this assumes homogeneous distribution of individuals and species among samples (Gotelli and Colwell, 2001)

Observed family diversity was also evaluated with commonly used diversity indices as well as more robust intrinsic diversity-based ordering methods. Taxonomic richness (S), Shannon's entropy $\left(H^{\prime}\right.$, Shannon, 1948$)$ and the Gini-Simpson diversity index ( $D$, Gini, 1912; Simpson, 1949) as well as their numbers equivalents were computed. Numbers equivalents express the richness of a hypothetical perfectly even community that is as diverse as the one observed (Jost, 2007; Jost, 2006; Patil and Taillie, 1982). Community evenness was also determined using Pielou's index of evenness ( $J^{\prime}$, Pielou, 1969).

The right tail-sum method (RTS) is a diversity ordering method that allows graphical comparisons of communities (Liu et al., 2007; Patil and Taillie, 1982; Tothmérész, 1998). It was shown to be more robust and stringent than other methods (Liu et al., 2007). Taxonomic groups are ranked by decreasing relative abundance, and the diversity profile is computed as: 


$$
T_{i}=\sum_{j=i+1}^{S} p_{[j]} \text { for } i=1,2, \ldots, S-1
$$

where $T_{i}$ is the RTS value at scale $i$ and $p_{[j]}$ is the relative abundance of the $j^{\text {th }}$ most abundant taxa. RTS is based on a clear definition of taxonomic diversity and is easily interpretable: communities that systematically have higher $T_{i}$ values are more diverse. However, if the profile for two communities cross, no conclusion can be drawn (Liu et al., 2007).

\subsubsection{Beta-diversity}

Despite the modest number of samples, multivariate analyses were conducted to better illustrate the similarities and differences among faunal samples. Principal component analysis (PCA) and Ward's hierarchical clustering were used for this ordination results compared with a Procrustean randomization test (Jackson 1995). The lowest available taxonomic level was used. Abundance data were first Hellingertransformed in order to preserve Hellinger, rather than Euclidian, distances in PCA (Legendre and Gallagher, 2001). The Hellinger distance has been shown to adequately estimate community resemblance (Legendre and Gallagher, 2001). The equilibrium contribution circle was computed to identify taxa having an important impact on the position of samples in the ordination (Legendre and Legendre, 1998). These results were used to formulate hypothesis about the influence of habitat conditions on the variation in taxonomic composition within and between microhabitats.

Finally, the Jaccard's similarity $\left(S_{\text {jacc }}\right)$ coefficient was used to quantify similarity in terms of shared taxa among samples within microhabitats (Jaccard, 1901). This coefficient does not consider the absence of taxa in both samples and has value between 0 and 1. Mean Jaccard similarity in each microhabitat was computed to evaluate within-group variation.

All analyses were performed in the $R$ environment $(R$, Development Core Team 2009). Rarefaction curves, diversity indices and diversity profiles were computed 
both with the Biodiversity R package (Kindt and Coe, 2005) and functions in Gauthier et al. (2010). Multivariate analyses were carried out using the Vegan package (Oksanen et al., 2008).

\section{Results}

3.1. Physico-chemical characterisation of microhabitats

\subsubsection{Sediment appearance}

The length of the tube cores varied from 12 to $20 \mathrm{~cm}$ depending on the nature of substratum (Table 1). Bio and Red exhibited visible differences in the upper $10 \mathrm{~cm}$ of sediment (Table 2). Based on the photographs taken on board, the oxygenated layer of brown sediments into the Bio sediment cores was thick (about $2 \mathrm{~cm}$ ) and clearly distinct from the black sediment below. On the contrary, only black sediment was visible in the cores from the Red microhabitat (Table 2).

\subsubsection{Salinity, temperature and $\mathrm{pH}$ at the sediment-water interface} Continuous measurements at the sediment-water interface showed no variation in salinity or temperature, either between the replicates of the Red microhabitat, or between the Red and Bio microhabitats. Overall, mean salinity was 38.8\%o and mean temperature $14.5^{\circ} \mathrm{C}$ (Table 2). $\mathrm{pH}$ in water samples from Red ranged from 7.89 to 7.94 (Table 2) and did not show important variation between replicates.

\subsubsection{Oxygen concentrations in pore water and methane concentrations at the} sediment-water interface

Oxygen data were only available for Red. Oxygen concentrations at the sedimentwater interface varied from 22.8 to $50.9 \mu \mathrm{mol} / \mathrm{l}$ among the three replicates (Table 2). Concentrations were much lower above Red2 where the oxygen depth penetration was the lowest $(0.6 \mathrm{~cm}$, Figure $3 \mathrm{a})$. This sample also exhibited by far the highest methane concentration at the sediment-water interface $(0.7 \mu \mathrm{mol} / \mathrm{l}$, Table 2$)$. Oxygen concentration at the sediment-water interface appeared positively correlated to oxygen depth penetration and negatively correlated to methane concentration at the water-sediment interface, but could not be statistically tested due to the small number of samples ( $n=3$, Table 2, Figure 3a). 

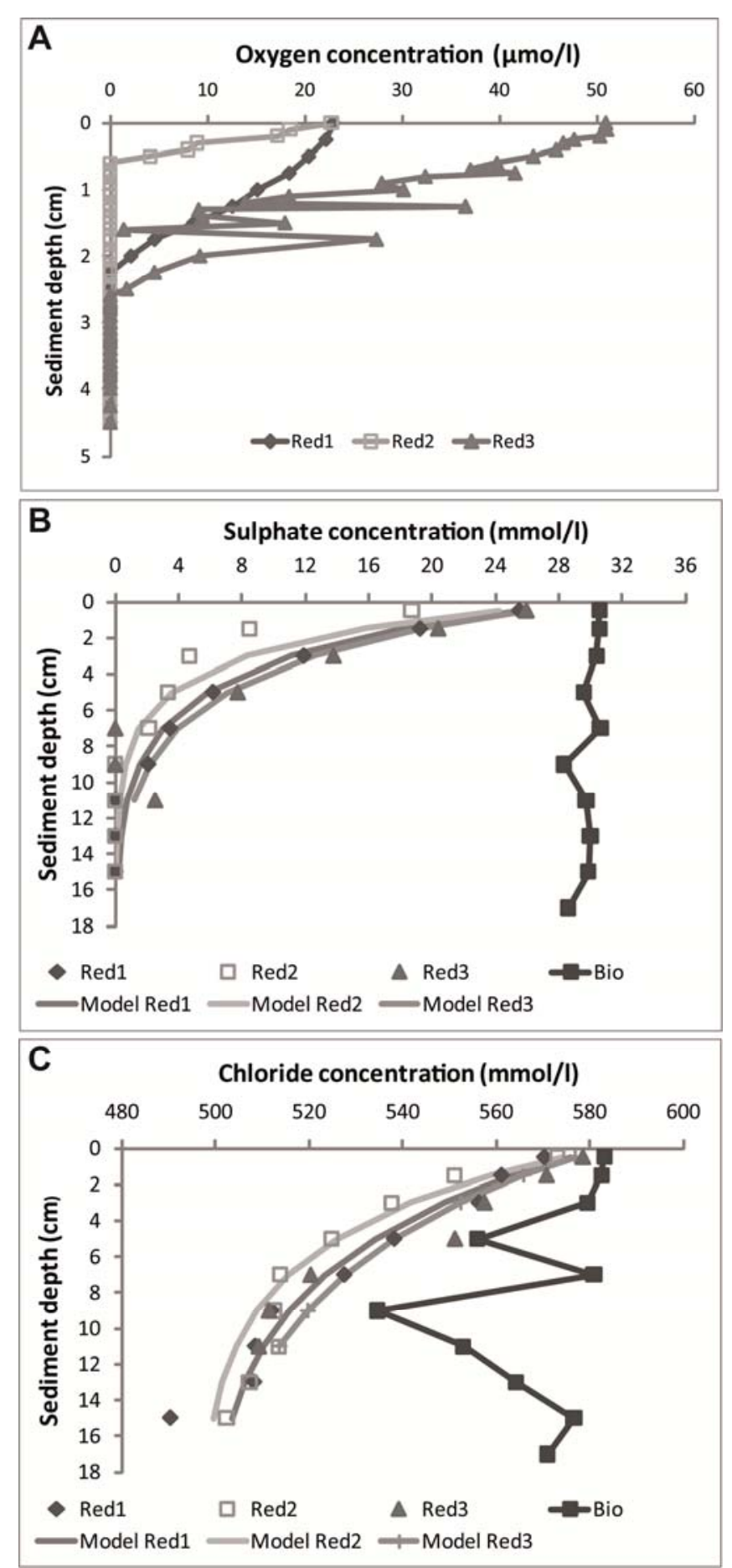

Fig. 3. (A) Dissolved oxygen, (B) sulphate and (C) chloride profiles measured in pore water extracted from sediment cores sampled in the bioturbated sediment (solid line $n=1$ ) and reduced sediment $(n=3)$ microhabitats in the Marmara Sea (MarNaut cruise, 2007). The model profiles are represented by dotted lines and explained in the text.

The $\mathrm{cm}$-thick carbonate crust sampled is composed of magnesian calcite. Three isotopic measurements were realized on this crust; the upper mm-thick white layer is 
underlain by a mm-thick light grey layer that covers a medium grey compact layer. The $\delta^{18} \mathrm{O}$ values (+2.40 to $+2.09 \% \mathrm{~V}$-PDB) are characteristic of calcite precipitated in equilibrium with the Marmara Sea bottom water ; the very low $\delta^{13} \mathrm{C}$ values $(-35.17$ to $-45.35 \%$ V-PDB) testify in favour of methane as the major source of carbon, oxidized as $\mathrm{CO}_{2}$ by methanotrophic bacteria (Aloisi et al., 2000; Gontharet et al., 2007; Pierre and Fouquet, 2007).

\subsubsection{Sulphate and chloride concentrations in pore water and estimation of the} upward flux velocity

In terms of sulphate and chlorinity, Bio and Red microhabitats exhibited distinctive profiles (Figures 3b, c). The single sulphate profile from Bio was higher than all those from Red. Sulphate concentrations in Bio stayed almost unchanged throughout the different sediment layers, varying from 28.3 to $30.6 \mathrm{mmol} / \mathrm{l}$ (Figure 3b). On the other hand, sulphate concentrations in Red decreased sharply in the first $2-3 \mathrm{~cm}$. All dropped to zero at depths of 7 to $11 \mathrm{~cm}$, but Red3 showed a new, slight surge at 11 $\mathrm{cm}$ (Figure 3b). The chlorinity profile in Bio presented sharp variations that were apparently independent of depth. Concentrations varied from 535 to $583 \mathrm{mmol} / \mathrm{l}$ and, as for sulphate, chloride concentration was higher at Bio than at Red (Figure 3c). Sulphate and chlorinity profiles were positively correlated within each microhabitat (Kendall's $\tau=0.9, \mathrm{p}<0.01$ in Bio; $\tau=0.7, \mathrm{p}<0.001$ in Red).

The theoretical advection-diffusion profiles of sulphate showed closer fits with actual data for Red1 and Red3. At Red2, the measured sulphate concentrations were lower in the first $4 \mathrm{~cm}$, but match the theoretical advection-diffusion profile at greater depths (Figure 3b). It is not possible to determine whether sulphate reduction occurs in Red.

The shape of the chloride concentration profiles in Red1, Red2 and Red3 reflects upward migration of interstitial water through the sediment layer (Figure 3c). Based on the advection-diffusion model, mean square best fits were obtained for upward velocities $(v)$ of $0.58 \pm 0.08 \mathrm{~m} / \mathrm{yr}, 0.75 \pm 0.1 \mathrm{~m} / \mathrm{yr}$ and $0.51 \pm 0.07 \mathrm{~m} / \mathrm{yr}$ for Red1, Red2 and Red3, respectively (Figure 3c). Despite the uncertainty linked to certain factors and the problems inherent to the diffusion of salts, we assumed that the effective diffusivity at our site ranged from 0.03 to $0.04 \mathrm{~m}^{2} / \mathrm{yr}$. Even though the pressure gradient was not measured, it is possible to give a lower bound to permeability in the 
Red microhabitat from the assumption that the pore pressure gradient probably does not exceed the local lithostatic pressure gradient. Therefore, for a porosity of $70 \%$ and hence a density of $1500 \mathrm{~kg} / \mathrm{m}^{3}$, this lower bound ranges from 2 to $4 \times 10^{-15} \mathrm{~m}^{2}$.

\subsection{Macro- and meiofaunal community description}

\subsubsection{Composition, abundance, density and $\alpha$-diversity}

Overall, a total of 524 and 4975 individuals were sampled from Bio and Red sediments, respectively, of which $35.5 \%$ and $4.2 \%$ were macrofauna sensu stricto. On carbonate crusts, a total of 3170 individuals were collected, among which $60.5 \%$ were macrofauna sensu stricto.

Relative macrofaunal abundances varied between both soft-sediment microhabitats (Bio and Red) and carbonate crusts and even between replicates of the same microhabitat (Table 3). In bioturbated sediments, bivalves and polychaetes were the dominant macrofaunal groups constituting $50 \%$ and $36 \%$ of the total abundance, respectively. Other groups were present, but in much lower abundances $(<5.4 \%$, Table 3). In the reduced sediments, all three replicates were very similar with a dominance of polychaetes that represented a mean of about $96 \%$ of the total macrofaunal abundance (Table 3). A few bivalves and gastropods were present. Finally, all three carbonate crust replicates were similar in terms of composition, but dominant taxa varied between samples. While $\mathrm{CC} 1$ and $\mathrm{CC} 2$ were dominated by rissoid gastropods (Laeviphitus verduini, Van Aartsen et al., 1989, from 64.6 to $72.2 \%)$, CC3 was dominated by an undescribed species of mytilid bivalve (68.8\%, Table 3). These bivalves shared morphological similarities with Idas modioliformis (Sturany, 1896) from the eastern Mediterranean Sea and a preliminary molecular study suggests that they may belong to the Bathymodiolinae family and even represent a new genus (Ritt et al. unpublished data). We also have molecular evidence suggesting that this mytilid may harbour symbiotic bacteria (Ritt et al. unpublished data). Cnidarians, polychaetes and crustaceans were also present on $\mathrm{CC}$ but in lower abundances. The fauna found at the bottom of the combined-sample box $\left(\mathrm{CC}_{\text {box }}\right)$ was largely dominated by rissoid gastropods $(40.5 \%$, Table 3$)$.

Despite the large sieve mesh size used $(250 \mu \mathrm{m})$, numerous meiofaunal specimens were found in our samples (Table 4). When added to macrofauna, they contributed 
from $17.7 \%$ to $98.3 \%$ of the total faunal abundance, with a lower impact in CC (Table 4). Nematodes were consistently the dominant taxon, representing $>79 \%$ of the meiofauna (Table 4). Copepods were the second most dominant meiofaunal taxon in Bio and CC, but were absent in Red. Only a few ostracods were observed in softsediment microhabitats $(<0.5 \%$, Table 4$)$.

Average macrofaunal densities varied from 3433 ind. $/ \mathrm{m}^{2}$ in Red, to $15325 \mathrm{ind} . / \mathrm{m}^{2}$ in $\mathrm{CC}$ with an intermediate value of $9300 \mathrm{ind} . / \mathrm{m}^{2}$ in Bio (Table 5). Compared to macrofauna, the meiofaunal density ranking showed the opposite trend with minimum densities in CC (10.4 ind./10 cm²) and maximum densities in Red (79.4 ind. $\left./ 10 \mathrm{~cm}^{2}\right)$. They were intermediate in the Bio microhabitat $\left(16.9 \mathrm{ind} . / 10 \mathrm{~cm}^{2}\right.$, Table $5)$.

Rarefaction curves based on macrofaunal data (Figure 4a) show that the sampling effort was insufficient, especially in Bio $(n=1)$ and Red $(n=3)$. Nevertheless, the single sample from Bio had the highest taxonomic richness. For $\mathrm{CC}(\mathrm{n}=3)$, the curve seems to level off, suggesting that most macrofaunal taxa was sampled (Figure 4a). However, the ranking of the three curves would probably remain the same with the addition of new macrofaunal samples and we can conclude with some confidence that the total taxonomic richness (S) was highest in Bio, lowest in Red and intermediate in CC (Figure 4a). Finally, the sharp increase of the Bio curves (Figure 4a) indicates that, with each additional individual sampled, the probability of it representing a new taxon was high. This pattern also demonstrates that Bio showed a more even taxon distribution than the two other microhabitats, a result that was confirmed by Pielou's index ( $J$ ', Table 5). Meiofaunal samples were largely dominated by nematods (from 79 to 100\%) that were not identified below the phylum level and most likely include several families and species. Hence, only family richness for copepods, ostracods and mites is reported in Table 5 as a measure of alpha-diversity. 

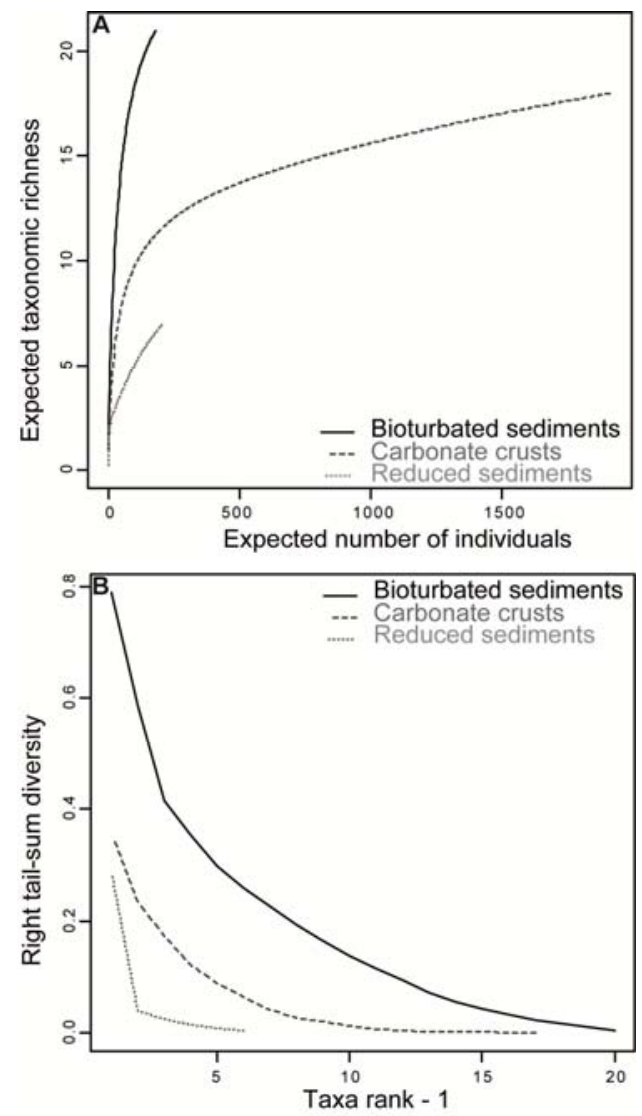

Fig. 4. Rarefaction curves (A) and right tail-sum (B) intrinsic diversity profiles according to the different microhabitats (MarNaut cruise, 2007). The $\mathrm{CC}_{\mathrm{Box}}$ data were included.

The right tail-sum (RTS) intrinsic diversity profiles (Figure 4b) confirmed that Bio had the highest evenness. The Bio curve is positioned above the two others and the most abundant taxon represented only about $20 \%$ of the total macrofaunal abundance. In Red, the dominant taxon represented nearly $70 \%$ of macrofaunal abundances (Figure 4b). Classical diversity indices, and their numbers equivalents (Table 5), give the same alpha-diversity ranking. Classic diversity indices gave a consistent ranking (CC>Bio>Red; Table 5).

\subsubsection{Symbiont-bearing fauna versus heterotrophic fauna}

Symbiont-bearing fauna were present in various proportions in Bio and CC microhabitats, and totally absent in Red. Overall, they represented about $3.8 \%$ of the abundance in the Bio microhabitat, compared to 8.9 to $68.8 \%$ in CC. Symbiontbearing fauna were represented by various bivalve families, including the Vesicomyidae, Lucinidae and Mytilidae. Live mytilids (adult and post-larvae) were only observed in CC (Table 3). However, dead specimens (post-larvae) were found 
in large numbers in both soft-sediment microhabitats, reaching higher densities in

488 Red. No data were available on the presence of symbiont-bearing fauna in the meiofaunal compartment.

3.2.3. Vertical distribution of the fauna within the sediments

The vertical distribution of the macrofauna varied among the two soft sediment microhabitats (Bio \& Red, Figure 5a). Although the distribution pattern varied slightly between the three Red replicates, the macrofauna observed in Red was concentrated in the uppermost sediment layers with most (up to 80\%) located within the top $3 \mathrm{~cm}$ (Figure 5a). In Bio, the fauna was more abundant in the very first layer (0-1 cm, 45\%) and distributed more evenly among the others. Abundance reached minimum values below $10 \mathrm{~cm}$ in all samples (Figure 5a).

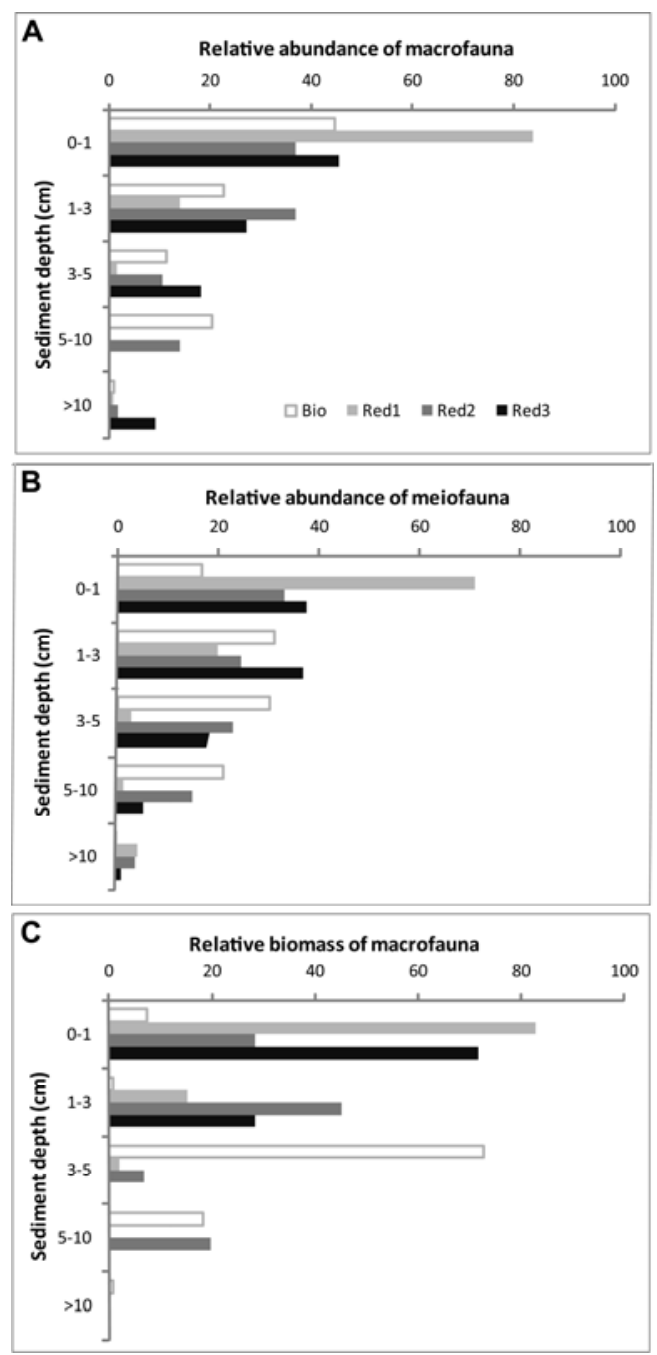

Fig. 5. Vertical distribution of (A) macrofaunal and (B) meiofaunal relative abundances and $(C)$ relative biomass of macrofaunal taxa according to depth in the two soft-sediment microhabitats. Bio= bioturbated sediments, $\mathrm{n}=1 ;$ Red $=$ reduced sediments, $\mathrm{n}=3$. 
Between 30 to $80 \%$ of meiofaunal abundance was observed in the first layers (0-1 $\mathrm{cm}$ ) of Red and then decreased gradually with depth (Figure 5b). In Bio, the distribution of meiofauna reached higher abundances in the 1-5 cm sediment layers. Nematodes were present at all depths (even $>10 \mathrm{~cm}$ ) whatever the microhabitat, whereas copepod crustaceans were restricted to the upper $10 \mathrm{~cm}$. As for macrofauna, meiofauna were rare in the deep sediment layer [>10 cm], they represented less than $5 \%$ of the total faunal abundance (Figure $5 b$ ).

\subsubsection{Macrofaunal biomass}

The highest macrofaunal biomass was found on CC reaching an average of $0.806 \mathrm{~kg}$ $\mathrm{ww} / \mathrm{m}^{2}$ (Table 5). Mytilids were the main contributors of this relatively high biomass. The biomass found at the bottom of the combined-sample box $\left(\mathrm{CC}_{\mathrm{box}}\right)$, was negligible, only reaching $0.0033 \mathrm{~kg}$. In the two other microhabitats, the mean biomass was $0.0018 \mathrm{~kg} \mathrm{ww} / \mathrm{m}^{2}$ on Bio and $0.0019 \mathrm{~kg} \mathrm{ww} / \mathrm{m}^{2}$ on Red (Table 5). The low values of biomass found in these microhabitats, compared to the crusts, were related to the presence of small organisms. Most of the biomass was found in the upper $5 \mathrm{~cm}$ of the sediments (Figure $5 \mathrm{c}$ ). While it was mostly concentrated in the top $3 \mathrm{~cm}$ in Red, it was highest at 3-5 cm depth in the Bio microhabitat (Figure 5c).

\subsubsection{Within and among microhabitat variation} Hierarchical clustering and PCA on macrofaunal abundances sensu stricto illustrate variations between the carbonate crusts and the two soft substratum microhabitats (Figure 6). The ordination clearly separates the three microhabitats along the two first axes that represent $77.4 \%$ of the total variance (Figure $6 \mathrm{a}$ ). The three microhabitats are separated along the first axis, which contains $48 \%$ of the variance in the faunal variation. Inter-microhabitat variability was larger than intra-microhabitat variability as all replicate samples from Red and CC microhabitats grouped together. On the second axis, the Red and CC microhabitats grouped together while Bio stood alone. This axis explained $29.4 \%$ of the variance in the faunal variation (Figure $6 a$ ). In terms of structuring taxa, the rissoid gastropods Laeviphitus verduini and the dorvilleid polychaetes contributed significantly to the two first axes, characterizing the CC microhabitat and the Red microhabitat, respectively (Figure 6a). Other taxa, such as the mytilid bivalves, were important, but to a lesser extent, in the positioning of the microhabitats on the two first axes (Figure 6a). 


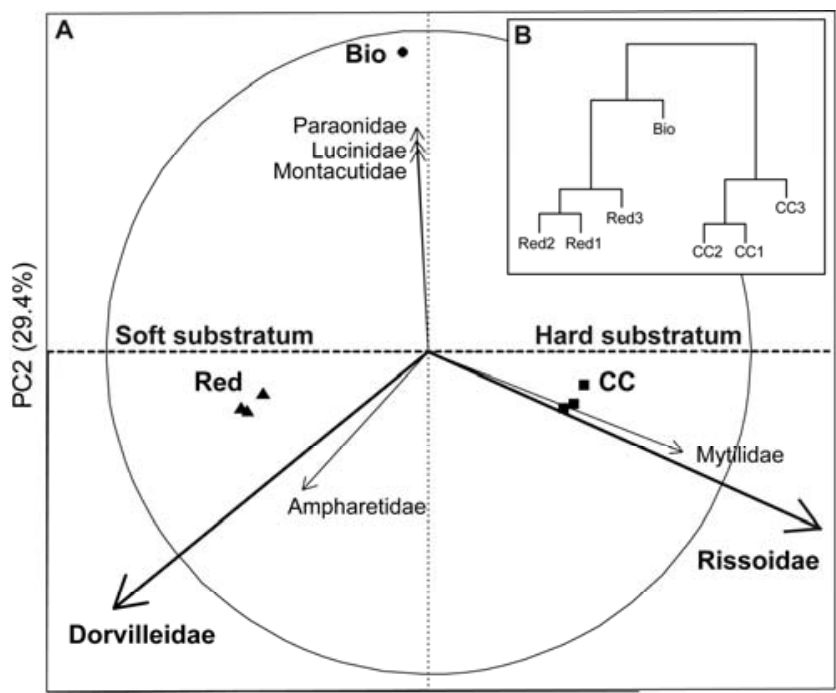

$\mathrm{PC} 1(48.0 \%)$

Fig. 6. (A) Ordination graph (PCA, scaling type 1) with the circle of equilibrium contribution (radius $=0.77$ ) and the two first axes representing $77.4 \%$ of the total variance. Vectors shorter than 0.42 were removed. (B) Ward's hierarchical clustering performed with Hellinger-transformed macrofaunal abundances of high taxonomic level data for each microhabitat type, Bio = bioturbated sediments, Red $=$ reduced sediments, $\mathrm{CC}=$ carbonate crust.

Interestingly, a PCA with Hellinger transformed meiofaunal data only (not shown) exhibited the same general distance patterns as the one with macrofauna sensu stricto (Procruste Test stat $=0.83, p=0.006,1000$ permutations). However, meiofauna sampling was very incomplete, especially on hard substratum, and these results might reflect this paucity of observations.

The three microhabitats could also be distinguished when considering only the polychaetes at the family level. Most families observed in the Bio microhabitat were absent in Red and vice versa (Table 3). Moreover, while at least eight families were present in the single Bio sample, and seven in CC, only four were observed in the three Red samples (Table 3). Siboglinid polychaetes were absent from our samples and were not observed in the seep areas that we explored in the Marmara Sea. Multivariate analysis performed on just the polychaete family abundances also separated the microhabitats along the two first axes, representing $79.3 \%$ of the total variance (Figure 7a). Bio was clearly distinct from Red and CC along the first axis, which explained $59.6 \%$ of the variance whereas the distinction along the second axis was not as clear (Figure 7a). Paraonidae and Dorvilleidae were the most important 
and Ampharetidae also had an important contribution on the second axis. Ward's hierarchical clustering corroborated this separation (Figure 7b). However, no clear distinction between the polychaete composition in $\mathrm{CC}$ and Red was established.

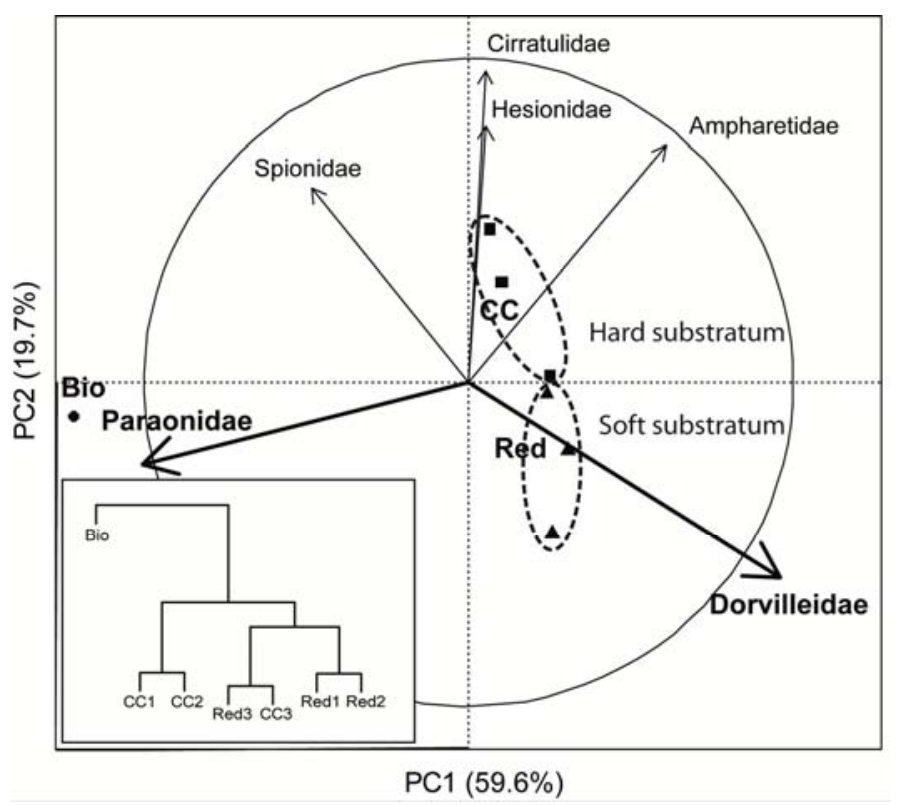

Fig. 7. (A) Ordination graph (PCA, scaling type 1) with the circle of equilibrium contribution (radius $=0.72$ ) and the two first axes representing $79.3 \%$ of the total variance. Vectors shorter than 0.56 were removed. (B) Ward's hierarchical clustering performed with Hellinger-transformed abundances of polychaete families data for each microhabitat type, Bio = bioturbated sediments, Red = reduced sediments, CC = carbonate crust. The possible link between the second axis and substratum type is noted.

The environmental and faunal results suggest a model of fluid circulation (Figure 8) that relates faunal composition and their patchy distribution to the flux of lowchlorinity fluid emissions. The upward flux was hypothesized to be higher under the Red microhabitat and lower under the Bio and CC microhabitats, where symbiontbearing bivalves, vesicomyids and mytilids, respectively, were living. Thus, these taxa appear to be reliable indicators of the presence of chemical fluxes, especially sulphides, at the sediment-water interface. 


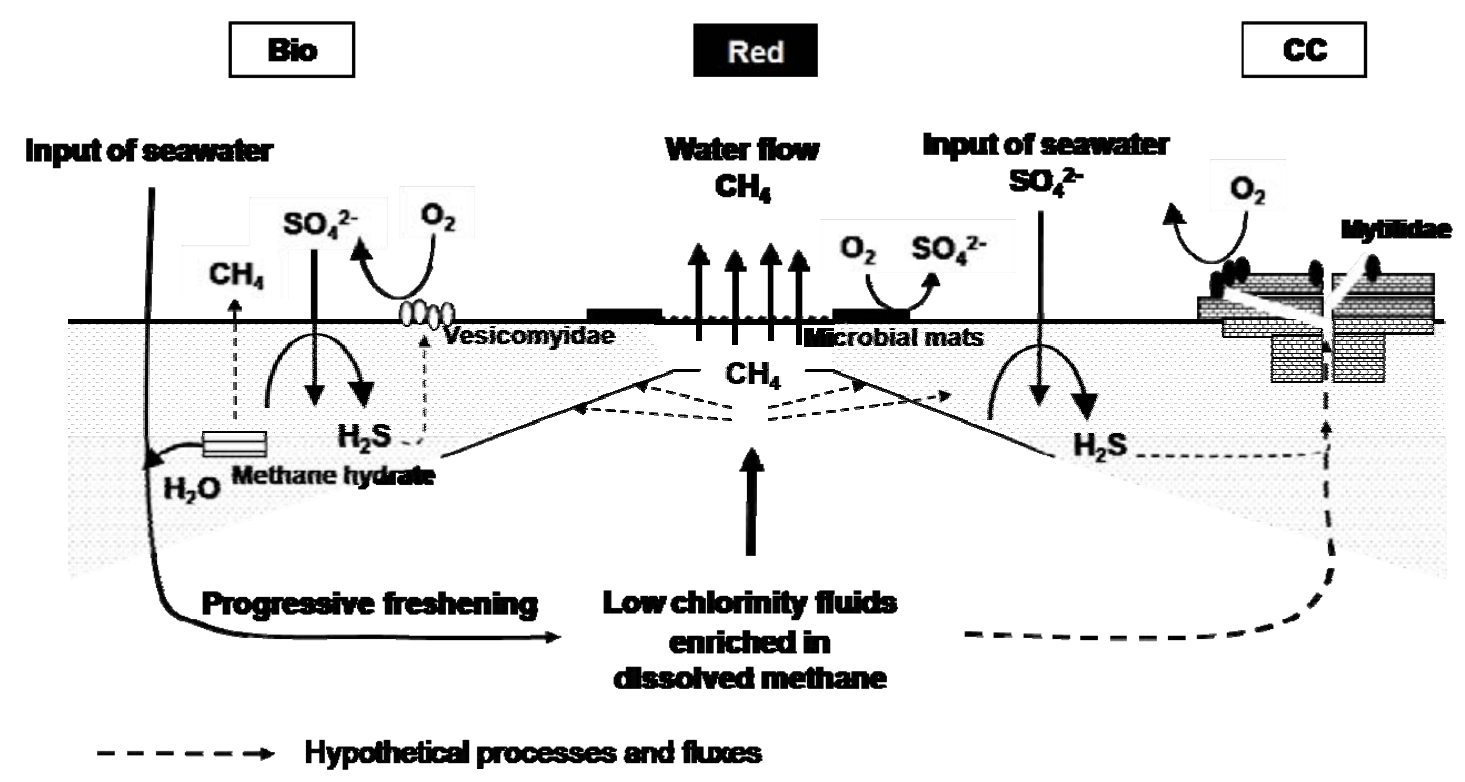

Fig. 8. Schematic hypothetical representation (modified from Henry et al., 1996 and Olu et al., 1996) of physical and chemical processes in the first few centimetres of sediments at each microhabitat type, Bio $=$ bioturbated sediments, Red $=$ reduced sediments, $\mathrm{CC}=$ carbonate crust. Doted line = hypothetical processes and fluxes. The distance between microhabitats is not drawn to scale.

\section{Discussion}

\subsection{Environmental conditions in the Marmara Sea}

The cold seeps of Marmara Sea illustrate an example of an active margin setting with low-chlorinity upward fluids. Contrary to other seep sites, the regions of the Marmara Sea explored in this study did not reveal spectacular evidence of fluid emissions on the seafloor, such as mud volcanoes, pockmarks or brine pools (Milkov, 2000; Hovland et al., 2002; Judd and Hovland, 2007). Instead, fluid fluxes appeared to be unevenly distributed along active faults where fractures allow released gas to escape or to filter through sediments (Geli et al., 2008; Zitter et al., 2008). Thermogenic methane-rich bubble emissions occur (Bourry et al., 2009) and brackish water can be expelled through chimneys on the seafloor (Zitter et al., 2008). Furthermore, black patches (reduced sediments) throughout the different basins have been observed within the larger Çinarcik basin where the dissolved oxygen concentration is the lowest. In fact, a gradient of dissolved oxygen in the water column is observed from the western to the eastern basins with concentrations reaching $50 \mu \mathrm{mol} / \mathrm{kg}$ in the Tekirdag basin, $25 \mu \mathrm{mol} / \mathrm{kg}$ in the Central basin and $8 \mu \mathrm{mol} / \mathrm{kg}$ in the Çinarcik basin (Lionel Finchel, INSU). The Marmara Sea is not as anoxic as the Black Sea, but pollution in the Marmara Sea due to anthropogenic activities (Cetecioglu et al., 2009) and the proximity of land lead to high inputs of organic matter that can reach the seafloor, enhancing microbial activity and organic matter degradation there. This is 
supported by the observation of huge fluxes of marine snow during diving, even in the deeper part of the Central basin at depths of up to $1200 \mathrm{~m}$.

Tectonic processes appear to play a major role in the occurrence of fluid emissions in this region and their highly dynamic nature may induce high spatial and temporal variation that may in turn influence faunal distribution (Zitter et al., 2008). This high spatial heterogeneity was apparent in the Red microhabitat, where replicates separated by only a couple of meters varied by as much as five fold in methane concentrations. The chemical data at the sediment-water interface (i.e. methane) as well as in pore water (i.e. sulphates, oxygen) confirmed the presence of fluid emission and provided evidence for seawater convection between the two softsediment microhabitats. Despite the incompleteness of our environmental factor dataset and the large within-microhabitat variations observed, our data suggest that both soft sediment microhabitats had a distinct chemical signature.

\subsection{Microhabitat characteristics}

\subsubsection{Bioturbated sediment microhabitat}

The Bio microhabitat was characterised by deeper oxygen and sulphate penetration. We can assume that the penetration of these elements in the sediments is favoured by the presence of burrows, probably built by crustaceans. It has been shown that complex burrows may influence the overall sedimentology and geochemistry of the seafloor and especially oxygen penetration (Aller, 1988; Ziebis et al., 1996). The jagged chlorinity profile can be interpreted as the consequence of transient diffusionadvection resulting from bio-irrigation. The sulphate concentrations remained relatively high and, with the exception of the lowest point at $16-18 \mathrm{~cm}$ depth, were compatible with mixing between seawater and a fluid of $100 \mathrm{mmol} / \mathrm{l}$ chlorinity and 0 $\mathrm{mmol} / \mathrm{l}$ sulphate, representative of fossil pore water originating from the ancient Marmara lake (Zitter et al., 2008). The top of the sulphate reduction zone lays $16 \mathrm{~cm}$ below the seafloor and likely to the end of the bio-irrigated zone. This type of system has already been observed at Nankai (Henry et al., 1992; Toki et al., 2004) or on the Barbados Trench (Henry et al., 1996), as explained below for the Red microhabitat.

The observed taxonomic richness was highest in the Bio microhabitat, even though only a single sample was collected. This microhabitat had intermediate macrofaunal 
densities and was dominated by bivalves - especially Montacutidae and Vesicomyidae -, polychaetes and nematodes. It is interesting to note that the vesicomyid Isorropodon perplexum (Sturany, 1896) and another symbiont-bearing species, the lucinid Lucinoma kazani (Salas and Woodside, 2002) have only been observed at Mediterranean Sea cold seeps where they are fuelled by the Anaerobic Oxydation of Methane (AOM) that induces $\mathrm{H}_{2} \mathrm{~S}$ production (Boetius et al., 2000). Vesicomyidae beds have already been observed at numerous cold seep sites with higher densities such as that around the centre of the Atalante mud volcano where they reach up to $10 \mathrm{ind} . / \mathrm{m}^{2}$ (Olu et al., 1996), or at the Nankai Trench where they reach 1000 ind. $/ \mathrm{m}^{2}$ (Henry et al., 1992). Vesicomyid and lucinid densities in Bio were much lower with up to 200 and $150 \mathrm{ind} . / \mathrm{m}^{2}$ respectively, but their presence was not only an indication of fluid venting but also of shallow sulphide production in this microhabitat. Both families are known to live half-buried in the sediments where they are able to extend their foot to capture sulphide (Barry and Kochevar, 1998; Wallmann et al., 1997). As supposed by the diffusion-advection model, the sulphide production in Bio may occur deep within sediments.

\subsubsection{Reduced sediment microhabitat}

The presence of methane at the interface of reduced sediment was the main evidence of seepage activity at the study site. This microhabitat was also characterised by low dissolved oxygen concentrations at the water-sediment interface and the sulphate profiles showed a sharp decrease in the first $10 \mathrm{~cm}$. However, contrary to dissolved oxygen, we cannot assume that sulphates decreased only by simple consumption in sediments. The model based on chlorinity profiles supported the hypothesis that the Red microhabitat corresponded to a zone of fairly uniform Darcian flow (i.e. within fluid velocities ranging 0.5-0.75 m/yr) for a fluid of constant chlorinity $(496 \mathrm{mmol} / \mathrm{l})$ and containing no sulphates. The ascending fluid appears to be a mix of seawater and brackish pore fluid that dilutes the chloride. In fact, the salinity of the brackish pore fluids contained in the Marmara Sea sediments a few tens of meters below the seafloor is only about $100 \mathrm{mmol} / \mathrm{l}$ (Zitter et al., 2008). This mixing model implies that convection occurs around the brackish springs at a larger scale (1-100 m) than the one investigated here. Hydrate dissociation may also explain the progressive freshening of seawater within sediments in seeps.

Nevertheless, no gas hydrates were found in our samples, although they do occur in 
different basins of the Marmara Sea where the conditions of pressure and temperature corresponded to the hydrate stability zone (Bourry et al., 2009).

According to the proposed fluid circulation model, the Red microhabitat was dominated by advective fluxes (0.4-0.8 m/yr) that were sufficient to inhibit inflow and to extend the sulphate reduction to the sediment surface. Hence, the depth at which sulphate penetrated into the sediments did not appear to be controlled by reaction rates but rather by competition with molecular diffusion in the vigorous ascending fluid flow. More sophisticated modelling would be required to determine actual reaction rates. Similar geochemical processes were also observed at the Nankai Trench (Henry et al., 1992; Toki et al., 2004) and at the Barbados accretionary prisms (Henry et al., 1996), two sites also characterised by low chlorinity upward fluxes.

In terms of fauna, the Red microhabitat was characterised by low taxonomic diversity, the absence of symbiont-bearing fauna, the lowest macrofaunal densities and the large dominance of two ubiquitous polychaete families: the non-sedentary Dorvilleidae and the tube-building Ampharetidae. These two families are typical of areas enriched in organic matter (Fauchald and Jumars, 1979). The presence of lowdiversity polychaete assemblages, dominated by one or two families, has been already observed in microbial mats from the Eel River basin, Hydrate Ridge and Gulf of Mexico ( Levin et al., 2003; Sahling et al., 2002; Robinson et al., 2004). In our study, Ampharetidae were the second-ranked polychaete taxa. Members of this family have been observed in large numbers at other reduced sediments sites such as at the Hikurangi Margin (New Zealand) where they reach a density of up to 72000 ind./m² (Sommer et al., 2009b). This site lies on an active margin at a depth similar to our study site $(\sim 1050 \mathrm{~m})$ with high concentrations of dissolved oxygen and methane at the water-sediment interface (197 $\mu \mathrm{mol} / / \mathrm{l}$ and $1962 \mu \mathrm{mol} / / \mathrm{l}$, respectively; Table 6). In our study, dorvilleid and ampharetid polychaetes may represent the main consumers of dissolved oxygen at the surface of the Red microhabitat and account for the low oxygen concentration, which never exceeded $51 \mu \mathrm{mol} / /$.

Meiofaunal densities, dominated by nematodes, were highest in the Red microhabitat, four times as great as those observed in the two other microhabitats. 
They were higher (from 1058 to $134800 \mathrm{ind} . / \mathrm{m}^{2}$ ) than those observed in the Black Sea at shallower depth (250 m, from 2397 to 52593 ind./m², Sergeeva and Gulin., 2007). Nevertheless, our meiofaunal densities were much lower than those observed on the Atalante mud volcano at the Barbados accretionary prism where nematode density reaches up to 8300000 ind./m² (Olu et al., 1997). However, the large sieve size used $(250 \mu \mathrm{m})$ lead to the underestimation of meiofaunal density in our study. The low similarity between replicates mostly reflected the differences in abundance due to the high spatial heterogeneity of meiofauna, but also to the sampling strategy used.

\subsubsection{Carbonate crust microhabitat}

Carbonate crusts are known to be formed in reducing environments with methane inputs being oxidized by micro-organisms involved in the AOM (Aloisi et al., 2002; Aloisi et al., 2000). However, their immediate environment may change after they have formed. The carbonate crusts sampled here occur as a cm-thick layer that covers a meter-high mound covered by sediments; this structure may be considered as chemoherms (Teichert et al., 2005) that are built by fluid flow and/or escape of free methane gas into the water column. The crust is composed of magnesian calcite that was the product of anaerobic oxidation of methane as evidenced by the very low $\partial^{13} \mathrm{C}$ value. However, additional chemical data will be necessary to gain a better understanding of this microhabitat and to position it within the gradient of environmental conditions observed in the two other microhabitats.

In terms of fauna, the $\mathrm{CC}$ microhabitat was characterized by intermediate diversity, the highest biomass and the highest macrofaunal densities, largely dominated by rissoid gastropods and by symbiont-bearing mytilids. The CC microhabitat exhibited the highest proportion of symbiont-bearing fauna and the occurrence of the latter was evidence of sufficient fluid flow and of exchanges between seawater and sediments to sustain symbiotic processes. Furthermore, this microhabitat harboured the highest percentage of symbiont-bearing fauna represented by mytilids that constitute the major part of the total biomass. Like Idas sp. from the Nile deep-sea fan, that lives in association with up to six different microbial symbionts (Duperron et al., 2008), the new mytilid species found in the Marmara Sea may harbour both thiotrophic and methanotrophic endosymbionts. To date our preliminary analyses only confirm the 
presence of thiotrophic endosymbionts (Ritt et al. unpublished data). As on the giant pockmark off West Africa (Olu-Le Roy et al., 2007), carbonate crusts with mytilids appear to be under the influence of high fluid flow, higher than in sediments with vesicomyids, but lower than in reduced sediments in our study case (Table 6).

\subsection{Comparison between microhabitats (at the local scale)}

Multivariate analyses showed a first distinction between communities found on hard and soft substratum microhabitats. The second axis could be related to a gradient of seepage influence (methane, oxygen and possibly sulphide). However, our chemical dataset was insufficient to establish statistical links between faunal distribution and environmental conditions and additional sampling would be necessary to further explore this hypothesis. The two distinct sediment microhabitats were characterized by contrasting methane supply and, probably, sulphide production. The Red microhabitat was dominated by upward advection of pore fluid that causes strong chemical gradients in the first few $\mathrm{cm}$. At the Bio microhabitat, the production of hydrogen sulphide probably occurs below the bioturbated layer and is most likely controlled by bioirrigation fluxes (Wallmann et al., 1997). While the strong chemical gradients at Red can be exploited by free-living bacteria, more complex species interactions such as symbiosis could become advantageous at a site where sulphide production and oxygen supply are separated by at least $15 \mathrm{~cm}$, as in Bio. Sulphidetolerant polychaetes and nematodes lived on the surface of Red, whereas symbiontbearing fauna, such as Vesicomyidae bivalves, were more evenly distributed and buried in Bio. The distribution patterns observed in our study support the hypothesis voiced by other authors suggesting that Ampharetidae and Dorvilleidae have a higher tolerance to sulphides (Levin et al., 2003; Sahling et al., 2002). Focusing only on polychaete families gives a different portrait. First of all, within-microhabitat variations appear to be proportionally more important than when considering the entire community. Also, Bio comes out as markedly different from all the others and the distinction between hard and soft substratum communities almost disappears.

These observations indicate that the faunal distribution at the Marmara Sea seeps is patchy and somewhat linked to the nature of the substratum and physico-chemical conditions that constrain the composition of the assemblages. Thus, within the same type of substratum (soft sediments), fluid flow velocities and chemical gradients such 
as methane, oxygen and possibly sulphide concentrations appear to play a role in faunal composition.

\subsection{Comparison between microhabitats (at the global scale)}

A total of 60 taxa, including meiofauna, were identified at our study site among which 8 were also observed at eastern Mediterranean sites so far (Olu-Le Roy et al., 2004). This suggests that exchanges between the eastern Mediterranean Sea and the Marmara Sea seep sites continue to occur or occurred in the past. However, Siboglinidae polychaetes were not observed, neither during the MARMARASCARPS cruise (Zitter et al., 2008), nor during our cruise. This is surprising since siboglinids are present at most Mediterranean seep sites studied (Olu-Le Roy et al., 2004; Ritt et al., in prep.). This may simply be due to the lack of sampling in this area. In fact, a siboglinid tube was found at $1000 \mathrm{~m}$ depth during a recent Turkish cruise in 2008 (L. Artüz, pers. com.). Another hypothesis is that the geographic barrier induced by the Dardanelle sill $(70 \mathrm{~m})$ may have limited siboglinid larval dispersion within the Marmara Sea but only additional sampling will help resolve this conundrum.

The flow velocity observed at our study site (0.4-0.8 m/yr) was much lower than those previously reported in the Nankai Trough accretionary wedge (Henry et al., 1992), the Cascadia subduction zone or the Peru continental margin (Linke et al., 1994), all of which fall into a much larger range of 10-1 $000 \mathrm{~m} / \mathrm{yr}$. These high rates are probably due to the combination of different factors, such as the geological setting, the presence of active thrusts, and the permeability of sediment layers (Henry et al., 2002). Furthermore, the distribution of the faunal communities in the Marmara Sea appears to differ from some large seep sites where a zonation of faunal communities has been observed at the $100 \mathrm{~m}$ to $\mathrm{km}$ scale (Le Pichon et al., 1990; Olu et al., 1996). This kind of ecological zonation has already been observed at larger scale on the Atalante mud volcano (Olu et al., 1996), the Håkon Mosby mud volcano (Niemann et al., 2006b), or the Hydrate Ridge (Sahling et al., 2002). The centre of the Atalante mud volcano is controlled by high fluid flux and colonised by high densities of nematodes, whereas clam beds are observed on the "Ridge zone", where the upward flux is lower. At the Håkon Mosby mud volcano, the active centre is only colonized by meiofaunal organisms, fauna form concentric belts around the active centre of the mud volcano (Jerosch et al., 2006) and this faunal distribution 
appears to be directly related to chemical gradients (Jerosch et al., 2006; Niemann et al., 2006b). At Hydrate Ridge, the flux under microbial mats is controlled by the dissociation of gas hydrate and the abiotic conditions are much harsher $(30 \mathrm{mmol} / \mathrm{l}$ sulphide) than within the surrounding sediments where the clams beds are found (Sahling et al., 2002). At sites such as the Hydrate and Blake ridges, changes in the faunal composition are linked to smaller spatial scales (Sahling et al., 2002; Van Dover et al., 2003). There, microbial mats colonise hydrate deposits with high sulphide concentrations; they are surrounded by vesicomyid beds and, further away, by solemyid beds, following a gradient in sulphide concentrations. The faunal distribution in the Marmara Sea appears to be characterised by similar small-scale patterns. Patches of reduced sediments were dominated by ampharetid and dorvilleid polychaetes and nematodes surrounded by microbial mats and the entire area was also surrounded by more highly oxygenated sediments colonised by Vesicomyidae and Lucinidae symbiont-bearing bivalves.

\section{On soft sediments, the faunal distribution seems strongly reliant on sulphide} production, which relies on the intensity of fluid flow. Indeed, a biological zonation was observed along a sulphide concentration gradient related to the occurrence of gas hydrates on the Cascadia margin (Sahling et al., 2002). Likewise, on the Håkon Mosby mud volcano, fluid flux gradient was related to faunal distribution patterns from the centre to the periphery (Niemann et al., 2006b). Methane concentrations measured above reduced sediments (Red, from 0.14 to $0.70 \mu \mathrm{mol} / \mathrm{l}$ ) match the lowest ranges observed at other seep sites (Table 6). Indeed, measured methane concentrations above seep faunal assemblages within reduced sediment microhabitats range from $0.14 \mu \mathrm{mol} / /$ (this study) to $1962 \mu \mathrm{mol} / / \mathrm{l}$ on the New Zealand margin (Sommer et al., 2009b, Table 6). Sediments filled with gas hydrates (and microbial mats) show the highest methane concentrations of all with concentrations of up to $6500 \mu \mathrm{mol} / \mathrm{l}$ (Table 6). Methane has been shown to influence the distribution of the fauna at other seep sites (Olu et al. 1997, Olu-Le Roy et al. 2007, Sergeeva and Gulin al., 2007).

Carbonate crusts may constitute an intermediate environment in terms of chemical gradients, and probably fluid intensity in the Marmara Sea, whereas they appear to 
be associated with highest methane concentrations and probably highest fluid flow at the Regab pockmark (Olu-Le Roy et al., 2007).

\subsection{Conclusion and perspective}

The Red microhabitat showed low taxonomic diversity and was dominated by surface deposit-feeders, whereas the Bio microhabitat harboured symbiont-bearing, burrowing species. In addition to chemical measurements and models based on them, we deduce that the Red microhabitat was influenced by fluids that prevent the establishment of non-tolerant species or even symbiotic species. On the other hand, Bio was also influenced by fluids but to a lesser extent, allowing an increase in diversity in association with an increase in trophic complexity and specialisation (i.e. symbioses). Interestingly, the CC microhabitat may sustain up to $69 \%$ of symbiontbearing fauna and especially mytilids, suggesting that fluid-flux exchanges between seawater and sediments are high enough to sustain symbiotic processes. These hard substratum microhabitats would be characterised by intermediate environmental conditions, harbouring higher biomass and densities and intermediate diversity. Additional sampling will be necessary to further explore the links between faunal distribution and environmental conditions in the Marmara Sea and to validate the proposed model.

We will soon complete the molecular phylogeny and morphological description of the new mytilid found on the Marmara carbonate crusts. Thus, our preliminary results suggested, that even though this species shared morphological similarities with Idas modioliformis (Sturany, 1896) from the eastern Mediterranean Sea, it may represent a new genus in the Bathymodiolinae family (Ritt et al. unpublished data). In addition, further analyses will be done to confirm the status of the bacteria as symbionts, visualize their distribution in the gills and define their nutritional role in this bivalve species.

Finally, adequate and representative sampling of the meiofaunal and microbial compartments, their activities and their trophic interactions as well as a complete environmental charaterization would be helpful in understanding the fine structure and functioning of the seep communities found in the Marmara deep basins. 


\section{Acknowledgments}

Captains and crew of R/V Atalante as well as Nautile's pilots are warmly acknowledged for their dedicated assistance and for contributing to the success of the cruise, especially dive 1665 . We thank Patricia Pignet for her valuable help with the chemical analyses. The faunal samples were identified by a network of taxonomists from the Muséum National d'Histoire Naturelle of Paris (France), the German Centre for Marine Biodiversity Research (Germany), the University of Lodz (Poland), the Russian Academy of Sciences of Moscow, the Kamchatka Branch of the Pacific Institute of Geography of Petropavlovsk-Kamchatsky and the Institute of Marine Biology of Vladivostok (Russia). The English was professionally edited by Carolyn Engel-Gautier. BR's thesis was funded by Ifremer. This research project benefited from funds from the HERMES and HERMIONE European projects (contract \# 511234 and \#226354) as well as ANR DEEP-OASES (ANR06BDV005) and from support from the GDR ECCHIS.

\section{References}

Aharon, P., Fu, B.S., 2003. Sulfur and oxygen isotopes of coeval sulphate-sulfide in pore fluids of cold seep sediments with sharp redox gradients. Chemical Geology 195 (1-4), 201-218.

Aller, R.C., 1988. Benthic Fauna and Biogeochemical Processes in Marine Sediments: the Role of Burrow Structures. In: Blackburn, T.H., Sorensen, J. (Eds.), Nitrogen Cycling in Coastal Environments. John Wiley \& Sons Ltd, pp. 301-329.

Aloisi, G., Bouloubassi, I., Heijs, S.K., Pancost, R.D., Pierre, C., Damste, J.S.S., Gottschal, J.C., Forney, L.J., Rouchy, J.M., 2002. CH4-consuming microorganisms and the formation of carbonate crusts at cold seeps. Earth and Planetary Science Letters 203 (1), 195-203.

Aloisi, G., Pierre, C., Rouchy, J.M., Foucher, J.P., Woodside, J., 2000. Methanerelated authigenic carbonates of eastern Mediterranean Sea mud volcanoes and their possible relation to gas hydrate destabilisation. Earth and Planetary Science Letters 184 (1), 321-338.

Alpar, B., 1999. Underwater signatures of the Kocaeli Earthquake (August 17th 1999). Turkish Journal of Marine Sciences 5, 111-130.

Ambraseys, N.N., 2000. The seismicity of the Marmara Sea area 1800-1899. Journal of Earthquake Engineering 4 (3), 377-401.

Ambraseys, N.N., Finkel, C.F., 1991. Long-terme seismicity of Istanbul and of the Marmara Sea region. Terra Nova 3 (5), 527-539. 
Ansal, A., Akinci, A., Cultrera, G., Erdik, M., Pessina, V., Tonuk, G., Ameri, G., 2009. Loss estimation in Istanbul based on deterministic earthquake scenarios of the Marmara Sea region (Turkey). Soil Dynamics and Earthquake Engineering 29 (4), 699-709.

Armijo, R., Flerit, F., King, G., Meyer, B., 2004. Linear elastic fracture mechanics explains the past and present evolution of the Aegean. Earth and Planetary Science Letters 217 (1-2), 85-95.

Armijo, R., Pondard, N., Meyer, B., Ucarkus, G., de Lepinay, B.M., Malavieille, J., Dominguez, S., Gustcher, M.A., Schmidt, S., Beck, C., Cagatay, N., Cakir, Z., Imren, C., Eris, K., Natalin, B., Ozalaybey, S., Tolun, L., Lefevre, I., Seeber, L., Gasperini, L., Rangin, C., Emre, O., Sarikavak, K., 2005. Submarine fault scarps in the Sea of Marmara pull-apart (North Anatolian Fault): implications for seismic hazard in Istanbul. Geochemistry Geophysics Geosystems 6, 29.

Artemov Yu. G., Egorov V.N., Polikarpov G.G., Gulin S.B., 2007. Methane emission on the hydro-and atmosphere by gas bubble streams in the Dniper paleo-delta, the Black Sea. Marine Ecological Journal 6 (3), 5-26.

Barry, J.P., Kochevar, R.E., 1998. A tale of two clams: differing chemosynthetic life styles among vesicomyids in Monterey Bay cold seeps. Cahiers De Biologie Marine 39 (3-4), 329-331.

Bayon, G. Loncke, L. Dupre, S., Ducassou, E., Duperron, S., Etoubleau, J., Foucher, J.P., Fouquet, Y., Gontharet, S., Huguen, C., Klaude, I., Mascle, J., Olu_Le Roy, K., Ondreas, H., Pierre, C., Sibuet, M., Stadnistskaia, A., Woodside, J., 2009. Multidisciplinary investigations of fluid seepage on an unstable margin: the case of the Central Nile deep-sea fan. Marine Geology 261, 92-104.

Bergquist, D.C., Fleckenstein, C., Knisel, J., Begley, B., MacDonald, I.R., Fisher, C.R., 2005. Variations in seep mussel bed communities along physical and chemical environmental gradients.

Bergquist, D.C., Ward, T., Cordes, E.E., McNelis, T., Howlett, S., Kosoff, R., Hourdez, S., Carney, R., Fisher, C.R., 2003. Community structure of vestimentiferangenerated habitat islands from Gulf of Mexico cold seeps. Journal of Experimental Marine Biology and Ecology 289 (2), 197.

Berner, R.A., 1974. Kinetic models for the early diagenesis of nitrogen, sulfur, phosphorus and silicon in anoxic marine sediments. In: Goldberg, E.D. (Ed.), Marine chemistry. The Sea: ideas and observations on progress in the study of the seas, pp. 427-450.

Boetius, A., Ravenschlag, K., Schubert, C.J., Rickert, D., Widdel, F., Gieseke, A., Amann, R., Jorgensen, B.B., Witte, U., Pfannkuche, O., 2000. A marine microbial consortium apparently mediating anaerobic oxidation of methane. Nature 407 (6804), 623-626.

Bourry, C., Chazallon, B., Charlou, J.L., Pierre Donval, J., Ruffine, L., Henry, P., Geli, L., Çagatay, M.N., Inan, S., Moreau, M., 2009. Free gas and gas hydrates from the 
Sea of Marmara, Turkey: chemical and structural characterization. Chemical Geology 264 (1-4), 197-206.

Campbell, K.A., 2006. Hydrocarbon seep and hydrothermal vent paleoenvironments and paleontology: past developments and future research directions.

Palaeogeography Palaeoclimatology Palaeoecology 232 (2-4), 362-407.

Cavanaugh, C.M., 1983. Symbiotic Chemoautotrophic Bacteria In MarineInvertebrates From Sulfide-Rich Habitats. Nature 302 (5903), 58-61.

Cetecioglu, Z., Ince, B.K., Kolukirik, M., Ince, O., 2009. Biogeographical distribution and diversity of bacterial and archaeal communities within highly polluted anoxic marine sediments from the Marmara Sea. Marine Pollution Bulletin 58 (3), 384-395.

Childress, J.J., Fisher, C.R., Brooks, J.M., Kennicutt, M.C., II, Bidigare, R., Anderson, A.E., 1986. A methanotrophic marine molluscan (Bivalvia, Mytilidae) symbiosis: Mussels fueled by gas. Science 233, 1306-1308.

Craig, H., 1957. Isotopic standards for carbon and oxygen and correction factors for mass-spectrometric analysis of carbon dioxide. Geochimica. et Cosmochimica. Acta 12, 133-149.

Dimitrov, L.I., 2002. Mud volcanoes - the most important pathway for degassing deeply buried sediments. Earth-Science Reviews 59 (1-4), 49-76.

Dubilier, N., Bergin, C., Lott, C., 2008. Symbiotic diversity in marine animals: the art of harnessing chemosynthesis. Nature Reviews Microbiology 6 (10), 725-740.

Duperron, S., Halary, S., Lorion, J., Sibuet, M., Gaill, F., 2008. Unexpected cooccurrence of six bacterial symbionts in the gills of the cold seep mussel Idas sp (Bivalvia : Mytilidae). Environmental Microbiology 10 (2), 433-445.

Egorov, V.N., Luth, U., Luth, C., Gulin, M.B., 1998. Gas seeps in the submarine Dniper Canyon Black Sea: acoustics, video and trawl data. In: Luth U., Luth C., Thiel H. (Eds), MEGASEEPS-Methane Gas Seeps Exploration in the Black Sea. Berichte aus dem Zentrum fu.r Meeres- und Klimatoforsch, Hamburg:14, 11-21.

Fauchald, K., Jumars, P.A., 1979. The diet of worms: a study of polychaete feeding guilds. Oceanography and Marine Biology Annual Review 17, 193-284.

Fisher, C.R., 1990. Chemoautotrophic And Methanotrophic Symbioses In MarineInvertebrates. Reviews in Aquatic Sciences 2 (3-4), 399-436.

Gage, J.D., 2003. Food inputs, Utilization, Carbon Flow and Energetics. Ecosystems of the Deep Oceans. Elsevier Science BV, pp. 313-380.

Gauthier, O., Sarrazin, J., Desbruyeres, D., 2010. Measure and mis-measure of species diversity in deep-sea chemosynthetic communities.

Geli, L., Henry, P., Zitter, T., Dupre, S., Tryon, M., Cagatay, M.N., de Lepinay, B.M., Le Pichon, X., Sengor, A.M.C., Gorur, N., Natalin, B., Ucarkus, G., Oezeren, S., Volker, D., Gasperini, L., Burnard, P., Bourlange, S., 2008. Gas emissions and active 
tectonics within the submerged section of the North Anatolian Fault zone in the Sea of Marmara. Earth and Planetary Science Letters 274 (1-2), 34-39.

Gini, C., 1912. Variabilità e Mutabilità. Tipographia di Paolo Cuppini, Bologna.

Gonfiantini, R., Stichler, W., Kozanski, K., 1995. Standards and intercomparison materials distributed by the International Atomic Energy Agency for stable isotope measurements. in: Reference and Intercomparison Materials for Stable Isotopes of Light Elements, IAEA-TECDOC-825, IAEA, Vienna, 13-29.

Gontharet, S., Pierre C., Blanc-Valleron, M.M., Rouchy, J.M., Fouquet, Y., Bayon, G., Foucher, J.P., Woodside, J., Mascle, J., and the NAUTINIL Scientific Party, 2007. Nature and origin of diagenetic carbonate crusts and concretions from mud volcanoes and pockmarks of the Nile deep-sea fan (eastern Mediterranean Sea). Deep Sea Research II 54, 1292-1311.

Gotelli, N.J., Colwell, R.K., 2001. Quantifying biodiversity: procedures and pitfalls in the measurement and comparison of species richness. Ecology Letters 4 (4), 379391.

Halbach, P., Holzbecher, E., Reichel, T., Moche, R., 2004. Migration of the sulphatemethane reaction zone in marine sediments of the Sea of Marmara - can this mechanism be tectonically induced? Chemical Geology 205 (1-2), 73-82.

Hecker, B., 1985. Fauna from a cold sulfur-seep in the Gulf of Mexico: comparison with hydrothermal vent communities and evolutionary implications. Bulletin of the Biological Society of Washington 6, 465-473.

Henry, P., Foucher, J.P., Le Pichon, X., Sibuet, M., Kobayashi, K., Tarits, P., Chamotrooke, N., Furuta, T., Schultheiss, P., 1992. Interpretation Of TemperatureMeasurements From The Kaiko-Nankai cruise - modeling Of Fluid-Flow In Clam Colonies. Earth and Planetary Science Letters 109 (3-4), 355-371.

Henry, P., Lallemant, S., Nakamura, K., Tsunogai, U., Mazzotti, S., Kobayashi, K., 2002. Surface expression of fluid venting at the toe of the Nankai wedge and implications for flow paths. International Symposium on Japan-France KAIKO-TOKAI Project - Tectonics of Subduction in the Nankai Trough. Elsevier Science Bv, Tokyo, Japan, pp. 119-143.

Henry, P., Le Pichon, X., Lallemant, S., Lance, S., Martin, J.B., Foucher, J.P., FialaMedioni, A., Rostek, F., Guilhaumou, N., Pranal, V., Castrec, M., 1996. Fluid flow in and around a mud volcano field seaward of the Barbados accretionary wedge: Results from Manon cruise. Journal of Geophysical Research-Solid Earth 101 (B9), 20297-20323.

Hessler, R.R., Jumars, P.A., 1974. Abyssal community analysis from replicate box cores in the central North Pacific. Deep Sea Research 21, 185-209.

Hovland, M., Gardner, J.V., Judd, A.G., 2002. The significance of pockmarks to understanding fluid flow processes and geohazards. Geofluids 2 (2), 127-136. 
Hubert-Ferrari, A., Barka, A., Jacques, E., Nalbant, S.S., Meyer, B., Armijo, R., Tapponnier, P., King, G.C.P., 2000. Seismic hazard in the Marmara Sea region following the 17 August 1999 Izmit earthquake. Nature 404 (6775), 269-273.

Hurlbert, S.H., 1971. The nonconcept of species diversity: a critique and alternative parameters. Ecology 52 (4), 577-586.

Iversen, N., Jørgensen, B.B., 1993. Diffusion coefficients of sulfate and methane in marine sediments: Influence of porosity. Geochimica et Cosmochimica Acta 57 (3), 571-578.

Jaccard, P., 1901. Dsitribution de la flore alpine dans le Bassin des Dranses et dans quelques régions voisines. Bulletin de la société vaudoise des sciences naturelles.

Jackson, D.A., 2005. PORTEST: a PROcustean randomization TEST of community environment concordance. Ecosciences 2, 297-303.

Jensen, P., Aagaard, I., Burke, R.A., Dando, P.R., Jorgensen, N.O., Kuijpers, A., Laier, T., Ohara, S.C.M., Schmaljohann, R., 1992. Bubbling Reefs In The Kattegat submarine landscapes of carbonate-cemented rocks support a diverse ecosystem at methane seeps. Marine Ecology Progress Series 83 (2-3), 103-112.

Jerosch, K., Schluter, M., Pesch, R., 2006. Spatial analysis of marine categorical information using indicator kriging applied to georeferenced video mosaics of the deep-sea Hakon Mosby Mud volcano. Ecological Informatics 1 (4), 391-406.

Jost, G., 2007. Partitioning diversity into independant alpha and beta components. Ecology 88, 2427-2439.

Jost, L., 2006. Entropy and diversity. Oikos 113, 363-375.

Judd, A.G., Hovland, M., 2007. Seabed Fluid Flow - The Impact on Geology, Biology and the Marine Environment.

Jumars, P.A., Hessler, R.R., 1976. Hadal community structure - implications from Aleutian trench. Journal of Marine Research 34 (4), 547-560.

Kendall, M.G., 1938. A new measure of rank correlation. Biometrika 30 (1-2), 81-93.

Kindt, R., Coe, R., 2005. Tree diversity analysis. A manual and software for common statistical methods for ecological and biodiversity studies. World Agroforestry Centre (ICRAF). Nairobi.

Le Pichon, X., Foucher, J.P., Boulegue, J., Henry, P., Lallemant, S., Benedetti, M., Avedik, F., Mariotti, A., 1990. Mud Volcano Field Seaward Of The Barbados Accretionary Complex - A Submersible Survey. Journal of Geophysical ResearchSolid Earth And Planets 95 (B6), 8931-8943.

Le Pichon, X., Sengor, A.M.C., Demirbag, E., Rangin, C., Imren, C., Armijo, R., Gorur, N., Cagatay, N., Mercier de Lepinay, B., Meyer, B., 2001. The active Main Marmara Fault. Earth and Planetary Science Letters 192 (4), 595. 
Legendre, P., Gallagher, E.D., 2001. Ecologically meaningful transformations for ordination of species data. Oecologia 129 (2), 271-280.

Legendre, P., Legendre, L., 1998. Numerical ecology, 2nd English ed.

Levin, L.A., 2005. Ecology of cold seep sediments: interactions of fauna with flow, chemistry and microbes. Oceanography and Marine Biology - An Annual Review, Vol. 43. Crc Press-Taylor \& Francis Group, Boca Raton, pp. 1-46.

Levin, L.A., Gage, J.D., 1998. Relationships between oxygen, organic matter and the diversity of bathyal macrofauna. Deep Sea Research Part II: Topical Studies in Oceanography 45 (1-3), 129.

Levin, L.A., Ziebis, W., Mendoza, G.F., Growney, V.A., Tryon, M.D., Mahn, C., Gieskes, J.M., Rathburn, A.E., 2003. Spatial heterogeneity of macrofauna at northern California methane seeps: influence of sulfide concentration and fluid flow. MEPS 265, 123-139.

Levin, L.A., Mendoza, G.F., 2007. Community structure and nutrition of deep methane-seep macrobenthos from the North Pacific (Aleutian) Margin and the Gulf of Mexico (Florida Escarpment). Marine Ecology-An Evolutionary Perspective 28 (1), 131-151.

Li, Y.-H., Gregory, S., 1974. Diffusion of ions in sea water and in deep-sea sediments. Geochimica et Cosmochimica Acta 38, 703-714.

Linke, P., Suess, E., Torres, M., Martens, V., Rugh, W.D., Ziebis, W., Kulm, L.D., 1994. In-Situ Measurement Of Fluid-Flow From Cold Seeps At Active Continental Margins. Deep-Sea Research Part I-Oceanographic Research Papers 41 (4), 721739.

Liu, C., Whittaker, R.J., Ma, K., Malcolm, J.R., 2007. Unifying and distinguishing diversity ordering methods for comparing communities. Population Ecology $49,89-$ 100.

Luth, C., Luth, U., Gebruk, A.V., Thiel, H., 1999. Methane gas seeps along the oxic/anoxic gradient in the Black Sea: manifestations, biogenic sediment compounds and preliminary results on benthic ecology. Marine Ecology-Pubblicazioni Della Stazione Zoologica Di Napoli I 20 (3-4), 221-249.

Luth, U., Luth, C., 1998 Benthic meiofauna and macrofauna of a methane seep area south-west of the Crimean Peninsula, Black Sea. In: Luth U., Luth C., Thiel H. (Eds), MEGASEEPS- Methane Gas Seeps Exploration in the Black Sea. Berichte aus dem Zentrum fuer Meeres- und Klimatoforsch, Hamburg 14, 113-126.

Menot, L., Galéron, J., Olu, K., Caprais, J.C., Crassous, P., Khripounoff, A., Sibuet, M., 2009. Spatial heterogeneity of macrofaunal communities in and near a giant pockmark area in the deep Gulf of Guinea. Marine Ecology.

Milkov, A.V., 2000. Worldwide distribution of submarine mud volcanoes and associated gas hydrates. Marine Geology 167 (1-2), 29-42. 
Niemann, H., Duarte, J., Hensen, C., Omoregie, E., Magalhaes, V.H., Elvert, M., Pinheiro, L.M., Kopf, A., Boetius, A., 2006a. Microbial methane turnover at mud volcanoes of the Gulf of Cadiz. Geochimica et Cosmochimica Acta 70 (21), 53365355.

Niemann, H., Losekann, T., de Beer, D., Elvert, M., Nadalig, T., Knittel, K., Amann, R., Sauter, E.J., Schluter, M., Klages, M., Foucher, J.P., Boetius, A., 2006b. Novel microbial communities of the Haakon Mosby mud volcano and their role as a methane sink. Nature 443 (7113), 854-858.

Oglesby, D.D., Mai, P.M., Atakan, K., Pucci, S., 2008. Dynamic models of earthquakes on the North Anatolian fault zone under the Sea of Marmara: Effect of hypocenter location. Geophysical Research Letters 35 (18), 4.

Oksanen, J., Kindt, R., Legendre, P., O'Hara, B., Simpson, G.L., Solymos, P., Henry, M., Stevens, H., Wagner, H., 2008. Vegan: Community Ecology Package. R package version 1.15-1., pp. http://cran.r-project.org/, http://vegan.r-forge.r-project.org/.

Olu, K., Lance, S., Sibuet, M., Henry, P., Fiala-Medioni, A., Dinet, A., 1997. Cold seep communities as indicators of fluid expulsion patterns through mud volcanoes seaward of the Barbados accretionary prism. Deep Sea Research Part I: Oceanographic Research Papers 44 (5), 811.

Olu, K., Sibuet, M., Harmegnies, F., Foucher, J.P., Fiala-Médioni, A., 1996. Spatial distribution of diverse cold seep communities living on various diapiric structures of the southern Barbados prism. Progress in Oceanography 38 (4), 347-356.

Olu-Le Roy, K., Caprais, J.C., Fifis, A., Fabri, M.C., Galeron, J., Budzinsky, H., Le Menach, K., Khripounoff, A., Ondreas, H., Sibuet, M., 2007. Cold-seep assemblages on a giant pockmark off West Africa: spatial patterns and environmental control. Marine Ecology-An Evolutionary Perspective 28 (1), 115-130.

Olu-Le Roy, K., Sibuet, M., Fiala-Medioni, A., Gofas, S., Salas, C., Mariotti, A., Foucher, J.-P., Woodside, J., 2004. Cold seep communities in the deep eastern Mediterranean Sea: composition, symbiosis and spatial distribution on mud volcanoes. Deep Sea Research Part I: Oceanographic Research Papers 51 (12), 1915.

Orphan, V.J., Ussler, W., Naehr, T.H., House, C.H., Hinrichs, K.U., Paull, C.K., 2004. Geological, geochemical, and microbiological heterogeneity of the seafloor around methane vents in the Eel River Basin, offshore California. Chemical Geology 205 (34), 265-289.

Patil, G.P., Taillie, C., 1982. Diversity as a Concept and its Measurement. Journal of the American Statistical Association 77 (379), 548-561.

Paull, C.K., Hecker, B., Commeau, R., Freeman-Lynde, R.P., Neumann, C., Corso, W.P., Golubic, S., Hook, J.E., Sikes, E., Curray, J., 1984. Biological communities at the Florida Escarpment resemble hydrothermal vent taxa. Science 226, 965-967.

Pielou, E.C., 1969. An introduction to mathematical ecology, New York. 
Pierre, C., Fouquet, Y., 2007. Authigenic carbonates from methane seeps of the Congo deep-dea fan. Geo Mar Lett 27, 249-257.

R, Development Core Team (2009). R: A Language and Environment for Statistical Computing. R Foundation for Statistical Computing. Vienna, Austria.

Rathburn, A.E., Levin, L.A., Tryon, M., Gieskes, J.M., Martin, J.B., Pérez, M.E., Fodrie, F.J., Neira, C., Fryer, G.J., Mendoza, G., McMillan, P.A., Kluesner, J., Adamic, J., Ziebis, W., 2009. Geological and biological heterogeneity of the Aleutian margin (1965-4822 m). Progress in Oceanography 80 (1-2), 22-50.

Ritt, B., Desbruyeres, D., Caprais, J.C., Khripounoff, A., Le Gall, C., Gauthier, O., Buscail, R., Olu, K., Sarrazin, J., in preparation. Cold seep communities in the deep eastern Mediterranean Sea: composition, spatial patters and environmental control on the Mediterranean Ridge mud volcanoes.

Robinson, C.A., Bernhard, J.M., Levin, L.A., Mendoza, G.F., Blanks, J.K., 2004. Surficial hydrocarbon seep infauna from the Blake Ridge (Atlantic Ocean, $2150 \mathrm{~m}$ ) and the Gulf of Mexico (690-2240 m). Marine Ecology-Pubblicazioni Della Stazione Zoologica Di Napoli I 25 (4), 313-336.

Sahling, H., Galkin, S.V., Salyuk, A., Greinert, J., Foerstel, H., Piepenburg, D., Suess, E., 2003. Depth-related structure and ecological significance of cold-seep communities-a case study from the Sea of Okhotsk. Deep Sea Research Part I: Oceanographic Research Papers 50 (12), 1391.

Sahling, H., Rickert, D., Lee, R.W., Linke, P., Suess, E., 2002. Macrofaunal community structure and sulfide flux at gas hydrate deposits from the Cascadia convergent margin, NE Pacific. Marine Ecology Progress Series 231, 121-138.

Salas, C., Woodside, J., 2002. Lucinoma kazani n. sp. (Mollusca: Bivalvia): evidence of a living benthic community associated with a cold seep in the Eastern Mediterranean Sea. Deep Sea Research Part I: Oceanographic Research Papers 49 (6), 991-1005.

Sarradin, P.M., Caprais, J.C., 1996. Analysis of dissolved gases by headspace sampling gas chromatography with column and detector switching. Preliminary results. Analytical Communications 33 (10), 371-373.

Sarrazin, J., Juniper, S.K., 1999. Biological characteristics of a hydrothermal edifice mosaic community. Marine Ecology-Progress Series 185, 1-19.

Sengor, A.M.C., Tuysuz, O., Imren, C., Sakinc, M., Eyidogan, H., Gorur, G., Le Pichon, X., Rangin, C., 2005. The North Anatolian Fault: a new look. Annual Review Of Earth and Planetary Sciences 33, 37-112.

Sergeeva, N.G. and Gulin, M.B., 2007. Meiobenthos from an active methane seepage area in the NW Black Sea. Marine Ecology 28: 152-159.

Shannon, C.E., 1948. A mathematical therory of communication. Bell System Technical Journal 27, 379-423, 623-656. 
Sibuet, M., Olu, K., 1998. Biogeography, biodiversity and fluid dependence of deepsea cold-seep communities at active and passive margins. Deep Sea Research Part II: Topical Studies in Oceanography 45 (1-3), 517.

Simpson, E.H., 1949. Measurement of Diversity. Nature 163, 688.

Sommer, S., Linke, P., Pfannkuche, O., Schneider, R., Reitz, A., Haeckel, M., Flögel, S., Hensen, C., 2009. Seabed methane emissions and the habitat of frenulate tubeworms on the Captain Arutyunov mud volcano (Gulf of Cadiz). Marine Ecology Progress Series 382, 69-86.

Sommer, S., Linke, P., Pfannkuche, O., Niemann, H., Treude, T., 2009b. Benthic respiration in a seep habitat dominated by dense beds of ampharetid polychaetes at the Hikurangi Maring (new Zealand). Marine Geology doi: 10.1016/j.margo.2009.06.003.

Sturany, R., 1896. Zoologische Ergebnisse VII. Mollusken I (Prosobranchier und Opisthobranchier; Scaphopoden; Lamellibranchier) gesammelt von S.M. Schiff "Pola" 1890-18. Denkschriften der Kaiserlichen Akademie der Wissenschaften, Mathematische-Naturwissenschaftlischen Classe 63, 1-36, pl.31-32.

Teichert, B.M.A., Bohrmann, G., Suess, E., 2005. Chemoherms on Hydrate Ridge Unique microbially-mediated carbonate build-ups growing into the water column. Palaeogeography Palaeoclimatology Palaeoecology 227 (1-3), 67-85.

Thistle, D., 2003. The Deep-Sea Floor: An Overview. Ecosystems of The Deep Ocean. Elsevier Science Bv, pp. 5-37.

Toki, T., Tsunogai, U., Gamo, T., Kuramoto, S., Ashi, J., 2004. Detection of lowchloride fluids beneath a cold seep field on the Nankai accretionary wedge off Kumano, south of Japan. Earth and Planetary Science Letters 228 (1-2), 37-47.

Tothmérész, B., 1998. On the characterization of scale-dependant diversity. Abstracta Bonatica 22, 149-156.

Torres, M.E., McManus, J., Hammond, D.E., de Angelis, M.A., Heeschen, K.U., Colbert, S.L., Tryon, M.D., Brown, K.M., Suess, E., 2002. Fluid and chemical fluxes in and out of sediments hosting methane hydrate deposits on Hydrate Ridge, OR, I: hydrological provinces. Earth and Planetary Science Letters 201 (3-4), 525-540.

Tunnicliffe, V., Juniper, S.K., Sibuet, M., 2003. Reducing environments of the DeepSea Floor. Ecosystems of the Deep Ocean. Elsevier Science Bv, Amsterdam, pp. 81110.

Van Aartsen, J.J., Borghi, C., Giusti, F., 1989. Remarks on the genus Benthonella (Rissoidae) in Europe. La Conchiglia.

Van Dover, C.L., Aharon, P., Bernhard, J.M., Caylor, E., Doerries, M., Flickinger, W., Gilhooly, W., Goffredi, S.K., Knick, K.E., Macko, S.A., Rapoport, S., Raulfs, E.C., Ruppel, C., Salerno, J.L., Seitz, R.D., Sen Gupta, B.K., Shank, T., Turnipseed, M., Vrijenhoek, R., 2003. Blake Ridge methane seeps: characterization of a soft- 
sediment, chemo synthetically based ecosystem. Deep-Sea Research Part IOceanographic Research Papers 50 (2), 281-300.

Van Gaever, S., Moodley, L., de Beer, D., Vanreusel, A., 2006. Meiobenthos at the Arctic Hakon Mosby Mud Volcano, with a parental-caring nematode thriving in sulphide-rich sediments. Marine Ecology Progress Series 321, 143-155.

Vanreusel, A., Andersen, A.C., Boetius, A., Connelly, D., Cunha, M.R., Decker, C., Hilario, A., Kormas, K.A., Maignien, L., Olu, K., Pachiadaki, M., Ritt, B., Rodrigues, C., Sarrazin, J., Tyler, P., Van Gaever, S., Vanneste, H., 2009. Biodiversity of Cold Seep Ecosystems Along the European Margins. Oceanography 22 (1), 110-127.

Wallmann, K., Linke, P., Suess, E., Bohrmann, G., Sahling, H., Schluter, M., Dahlmann, A., Lammers, S., Greinert, J., von Mirbach, N., 1997. Quantifying fluid flow, solute mixing, and biogeochemical turnover at cold vents of the eastern Aleutian subduction zone. Geochimica et Cosmochimica Acta 61 (24), 5209-5219.

Ziebis, W., Forster, S., Huettel, M., Jorgensen, B.B., 1996. Complex burrows of the mud shrimp Callianassa truncata and their geochemical impact in the sea bed. Nature 382, 619-622.

Zitter, T.A.C., Henry, P., Aloisi, G., Delaygue, G., Cagatay, M.N., de Lepinay, B.M., Al-Samir, M., Fornacciari, F., Tesmer, M., Pekdeger, A., Wallmann, K., Lericolais, G., 2008. Cold seeps along the main Marmara Fault in the Sea of Marmara (Turkey). Deep-Sea Research Part I-Oceanographic Research Papers 55 (4), 552-570. 
Table 1

Sample locations, depth, sampling effort, and gear used to perform physico-chemical and faunal sampling in the three most common microhabitats of the north-eastern Central basin in the Marmara Sea explored during the MarNaut cruise in 2007. The length of the sediment cores and the estimated surface area of each carbonate crust sample are also reported.

\begin{tabular}{|c|c|c|c|c|c|c|}
\hline \multirow[t]{2}{*}{ Microhabitat types } & \multirow{2}{*}{$\begin{array}{l}\text { Latitude } \\
\qquad\left({ }^{\circ} \mathrm{N}\right)\end{array}$} & \multirow{2}{*}{$\begin{array}{l}\text { Longitude } \\
\left.\text { ( }{ }^{\circ} \mathrm{E}\right)\end{array}$} & \multirow{2}{*}{$\begin{array}{l}\text { Depth } \\
\text { (m) }\end{array}$} & \multicolumn{2}{|c|}{ Physico-chemical sampling } & \multirow[t]{2}{*}{ Faunal sampling } \\
\hline & & & & Interface water & Pore water in sediments & \\
\hline $\begin{array}{l}\text { Bioturbated sediments } \\
\text { (Bio) }\end{array}$ & $40^{\circ} 51.28$ & $28^{\circ} 10.20^{\prime}$ & 1122 & $\begin{array}{l}\text { 1x1 minute MicroCat } \\
\text { measurements: } \\
\text { temperature, salinity }\end{array}$ & $\begin{array}{l}2 \text { tube cores: } \\
\mathrm{SO}_{4}{ }^{2-}, \mathrm{Cl}^{-} \text {profiles }\end{array}$ & $\begin{array}{l}1 \text { blade core: } \\
\text { Bio }(13 \mathrm{~cm})\end{array}$ \\
\hline $\begin{array}{l}\text { Reduced sediments } \\
\text { (Red) }\end{array}$ & $40^{\circ} 51.27^{\prime}$ & $28^{\circ} 10.19^{\prime}$ & 1121 & $\begin{array}{l}3 \times 1 \text { minute MicroCat } \\
\text { measurements: } \\
\text { temperature, salinity } \\
3 \times 2 \text { water samples: } \\
\mathrm{CH}_{4}, \mathrm{pH}\end{array}$ & $\begin{array}{l}3 \times 2 \text { tube cores: } \\
\mathrm{O}_{2}, \mathrm{SO}_{4}{ }^{2-}, \mathrm{Cl}^{-} \text {profiles }\end{array}$ & $\begin{array}{l}3 \text { blade cores: } \\
\text { Red1 }(12 \mathrm{~cm}) \\
\text { Red2 }(20 \mathrm{~cm}) \\
\text { Red3 }(12 \mathrm{~cm})\end{array}$ \\
\hline $\begin{array}{l}\text { Carbonate crusts } \\
\text { (CC) }\end{array}$ & $40^{\circ} 51.27^{\prime}$ & $28^{\circ} 10.19^{\prime}$ & 1111 & None & None & $\begin{array}{c}3 \text { pieces of crust: } \\
\text { CC1 }\left(459 \mathrm{~cm}^{2}\right) \\
\text { CC2 }\left(368 \mathrm{~cm}^{2}\right) \\
\text { CC3 }\left(189 \mathrm{~cm}^{2}\right) \\
+\mathrm{CC}_{\text {Box }}\end{array}$ \\
\hline
\end{tabular}


Table 2

Visual observations of sediment colour in the Bio and Red microhabitats. Temperature, salinity, dissolved oxygen and methane concentrations and $\mathrm{pH}$ measurements at the sediment-water interface in microhabitat samples from the Marmara Sea are also given (MarNaut cruise, 2007).

\begin{tabular}{ccccccc}
\hline & Visual observations & Temperature & Salinity & {$\left[\mathrm{O}_{2}\right]$} & {$\left[\mathrm{CH}_{4}\right]$} & pH \\
\hline Bio & $\begin{array}{c}\text { Brown sediments at the } \\
\text { top, reduced sediments } \\
\text { the bottom }\end{array}$ & 14.52 & 38.77 & - & - & - \\
Red1 & Reduced sediments & 14.52 & 38.76 & $22.9 \pm 13.1 \mu \mathrm{M}$ & $0.33 \pm 0.04 \mu \mathrm{M}$ & $7.93 \pm 0.01$ \\
Red2 & $\begin{array}{c}\text { throughout core } \\
\text { Red3 }\end{array}$ & 14.52 & 38.76 & $22.8 \mu \mathrm{M}$ & $0.7 \pm 0.28 \mu \mathrm{M}$ & $7.94 \pm 0.02$ \\
\hline
\end{tabular}


Table 3

Relative macrofaunal $(>250 \mu \mathrm{m})$ abundances (\%) and total absolute abundances in the three microhabitats studied: bioturbated sediment (Bio, $n=1)$, reduced sediment (Red, $n=3)$ and carbonate crust $(C C, n=3)$ microhabitats. Specimens recovered at the bottom of the sampling box $\left(\mathrm{CC}_{\mathrm{Box}}\right)$ are also reported. Total relative abundance from each taxonomic group is highlighted in bold. All samples are from the north-eastern Central basin in the Marmara Sea (MarNaut cruise, 2007). * Taxonomic level used for alpha-diversity analyses.

\begin{tabular}{|c|c|c|c|c|c|c|c|c|c|c|}
\hline Taxonomic groups & & \multicolumn{4}{|c|}{ Reduced sediments } & \multicolumn{5}{|c|}{ Carbonate crusts } \\
\hline Porifera (Total) & 0 & 0 & 0 & 0 & 0 & 0 & 0 & 0 & 0 & 0.65 \\
\hline Cnidaria (Total) & 0 & 0 & 0 & 0 & 0 & 8.24 & 1.16 & 1.08 & $3.49 \pm 4.11$ & 0 \\
\hline \multicolumn{11}{|l|}{ Anthozoa - Zoantharia } \\
\hline Isozoanthus sp.1 & 0 & 0 & 0 & 0 & 0 & 0.12 & 0.12 & 0 & $0.08 \pm 0.07$ & 0 \\
\hline Isozoanthus sp.2 & 0 & 0 & 0 & 0 & 0 & 7.50 & 0 & 0 & $2.50 \pm 4.33$ & \\
\hline \multicolumn{11}{|l|}{ Anthozoa - Actiniaria } \\
\hline Sagartiidae* & 0 & 0 & 0 & 0 & 0 & 0.62 & 1.04 & 1.08 & $0.84 \pm 0.23$ & 0 \\
\hline Sagartiogeton sp. & 0 & 0 & 0 & 0 & 0 & 0.62 & 0.81 & 1.08 & $0.84 \pm 0.23$ & 0 \\
\hline Ampharetidae* & 0.54 & 29.46 & 3.52 & 54.54 & $29.17 \pm 25.52$ & 4.31 & 7.45 & 2.15 & $4.64 \pm 2.67$ & 11.77 \\
\hline Capitellidae* & 0 & 0 & 0 & 0 & 0 & 0 & 0.12 & 0 & $0.04 \pm 0.07$ & 0 \\
\hline Cirratulidae* & 0 & 0 & 0 & 0 & 0 & 4.55 & 0.35 & 0 & $1.63 \pm 2.53$ & 1.96 \\
\hline Cossuridae* $^{*}$ & 1.61 & 0 & 0 & 0 & 0 & 0 & 0 & 0 & 0 & 0 \\
\hline Dorvilleidae* & 0 & 69.77 & 91.23 & 27.27 & $62.76 \pm 32.55$ & 5.04 & 6.17 & 1.08 & $4.10 \pm 2.68$ & 2.61 \\
\hline Flabelligeridae* & 1.08 & 0 & 0 & 0 & 0 & 0 & 0 & 0 & 0 & 0 \\
\hline Hesionidae* & 0 & 0 & 0 & 0 & 0 & 1.72 & 1.40 & 0 & $1.04 \pm 0.91$ & 1.96 \\
\hline Lumbrineridae* & 2.69 & 0 & 0 & 0 & 0 & 0 & 0 & 0 & 0 & 0 \\
\hline Paraonidae* & 20.43 & 0 & 0 & 0 & 0 & 0 & 0 & 0 & 0 & 0 \\
\hline Pholoidae* & 0 & 0 & 1.75 & 0 & $0.58 \pm 1.01$ & 0 & 0 & 0 & 0 & 0 \\
\hline Lucinoma kazani & 1.61 & 0 & 0 & 0 & 0 & 0 & 0 & 0 & 0 & 0 \\
\hline Myrtea amorpha & 0 & 0 & 0 & 0 & 0 & 0 & 0 & 0 & 0 & 1.31 \\
\hline Unid. Lucinidae & 18.28 & 0 & 0 & 0 & 0 & 0 & 0 & 0 & 0 & 0 \\
\hline Mytilidae* & 0 & 0 & 0 & 0 & 0 & 10.08 & 8.84 & 68.81 & $29.25 \pm 34.27$ & 9.15 \\
\hline Mytilidae nov. sp. & 0 & 0 & 0 & 0 & 0 & 10.08 & 8.84 & 68.81 & $29.25 \pm 34.27$ & 9.15 \\
\hline Vesicomyidae* & 2.15 & 0 & 0 & 0 & 0 & 0 & 0 & 0 & 0 & 7.84 \\
\hline Isorropodon perplexum & 1.61 & 0 & 0 & 0 & 0 & 0 & 0 & 0 & 0 & 7.84 \\
\hline Unid. Vesicomyidae & 0.54 & 0 & 0 & 0 & 0 & 0 & 0 & 0 & 0 & 0 \\
\hline Yoldiidae* & 5.38 & 0.77 & 0 & 0 & $0.26 \pm 0.45$ & 0 & 0 & 0 & 0 & 0 \\
\hline Yoldiella striolata & 5.38 & 0.77 & 0 & 0 & $0.26 \pm 0.45$ & 0 & 0 & 0 & 0 & 0 \\
\hline Sareptidae* & 2.69 & 0 & 0 & 0 & 0 & 0 & 0 & 0 & 0 & 0 \\
\hline Montacutidae* & 16.67 & 0 & 0 & 0 & 0 & 0 & 0 & 0 & 0 & 0 \\
\hline Unid. Famillies* & 3.23 & 0 & 0 & 0 & 0 & 0.25 & 0.12 & 0 & $0.12 \pm 0.12$ & 6.54 \\
\hline
\end{tabular}




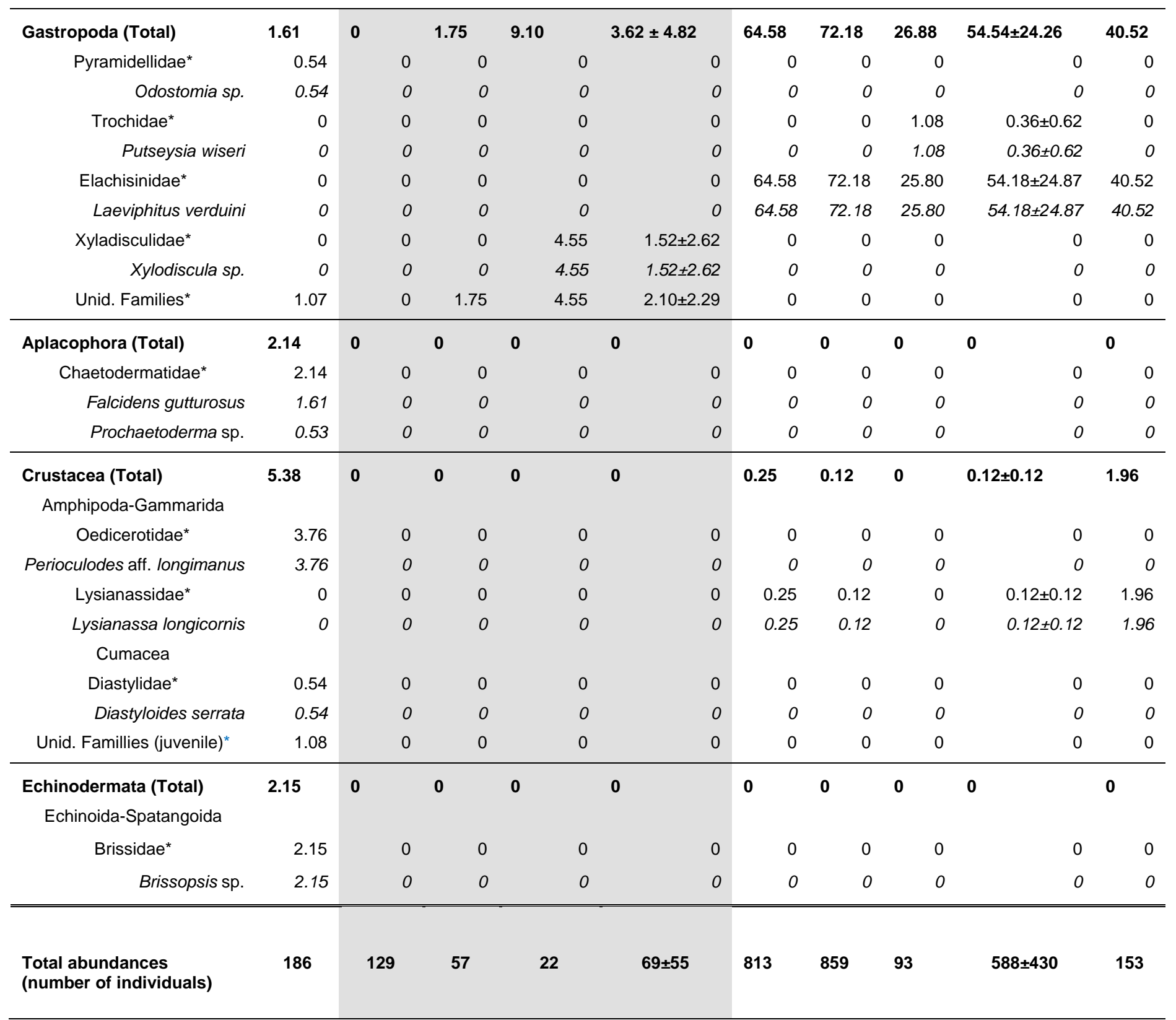

1270 


\section{Table 4}

Relative meiofaunal abundances (\%) and total absolute abundances in the three microhabitats studied: bioturbated sediment (Bio, $n=1$ ), reduced sediment (Red, $n=3)$ and carbonate crust $(C C, n=3)$ microhabitats. All samples are from the north-eastern part of the Central basin of the Marmara Sea (MarNaut cruise, 2007). $\left.{ }^{* *}\right)$ This proportion is largely underestimated since only the meiofauna $>250 \mu \mathrm{m}$ was sampled. No meiofauna was found in $\mathrm{CC}_{\mathrm{Box}}{ }^{*}$ Taxonomic level used for alpha-diversity analyses.

\begin{tabular}{|c|c|c|c|c|c|c|c|c|c|}
\hline \multirow[t]{2}{*}{ Taxa } & \multirow[b]{2}{*}{ Bio } & \multicolumn{4}{|c|}{ Reduced sediments } & \multicolumn{4}{|c|}{ Carbonate crusts } \\
\hline & & Red1 & Red2 & Red3 & Avg..SD & CC1 & $\mathrm{CC2}$ & $\mathrm{CC} 3$ & Avg..SD \\
\hline Nematoda* (Total) & 79.88 & 99.81 & 99.74 & 100 & $99.85 \pm 0.13$ & 79.03 & 95.68 & 85.00 & $86.58 \pm 8.43$ \\
\hline Crustacea (Total) & 18.66 & 0.19 & 0.26 & 0 & $0.15 \pm 0.13$ & 20.97 & 4.32 & 15.00 & $13.43 \pm 8.44$ \\
\hline \multicolumn{10}{|l|}{ Copepoda-Harpacticoida } \\
\hline \multicolumn{10}{|l|}{ Miraciidae* } \\
\hline Typhamphiascus confusus & 13.12 & 0 & 0 & 0 & 0 & 16.83 & 0.32 & 15.00 & $10.72 \pm 9.05$ \\
\hline $\begin{array}{l}\text { Typhamphaiscus sp. } \\
\text { Ameiridae* }^{*}\end{array}$ & \multicolumn{8}{|c|}{ Ameiridae* } & 0 \\
\hline Amphiascus sp. & 0 & 0 & 0 & 0 & 0 & 1.65 & 1.28 & 0 & $0.98 \pm 0.87$ \\
\hline Ameira longipes & 0 & 0 & 0 & 0 & 0 & 0.33 & 0 & 0 & $0.11 \pm 0.19$ \\
\hline Ameridae n. gen. & 0 & 0 & 0 & 0 & 0 & 0.17 & 1.12 & 0 & $0.43 \pm 0.60$ \\
\hline $\begin{array}{l}\text { Haifamera archibenthoica } \\
\text { Pseudotachidiidae* }\end{array}$ & \multicolumn{8}{|c|}{ Pseudotachidiidae* } & $0.05 \pm 0.09$ \\
\hline Pseudotachidius coronatus & 0.29 & 0 & 0 & 0 & 0 & 0 & 0 & 0 & 0 \\
\hline \multicolumn{10}{|l|}{ Tisbidae* } \\
\hline Tisbella sp. & 0 & 0 & 0 & 0 & 0 & 0.83 & 0.64 & 0 & $0.49 \pm 0.43$ \\
\hline \multicolumn{10}{|l|}{ Laophontidae* } \\
\hline Archesola typhlops & 0 & 0 & 0 & 0 & 0 & 0.17 & 0 & 0 & $0.06 \pm 0.10$ \\
\hline Harpacticoida Juvenile & 1.75 & 0 & 0 & 0 & 0 & 0.99 & 0.64 & 0 & $0.54 \pm 0.50$ \\
\hline \multicolumn{10}{|l|}{ Copepoda-Cyclopoida } \\
\hline \multicolumn{10}{|l|}{ Cyclopinidae* } \\
\hline Cyclopina sp.1 & 0.88 & 0.15 & 0 & 0 & $0.05 \pm 0.09$ & 0 & 0 & 0 & 0 \\
\hline Cyclopina sp.2 & 0.29 & 0 & 0 & 0 & 0 & 0 & 0 & 0 & 0 \\
\hline \multicolumn{10}{|l|}{ Copepoda-Calanoida } \\
\hline Unid. Calanoida* & 0 & 0 & 0 & 0 & 0 & 0 & 0.16 & 0 & $0.05 \pm 0.09$ \\
\hline \multicolumn{10}{|l|}{ Ostracoda } \\
\hline \multicolumn{10}{|l|}{ Cytherellidae* } \\
\hline Cytherella vulgata & 0.29 & 0 & 0 & 0 & 0 & 0 & 0 & 0 & 0 \\
\hline \multicolumn{10}{|l|}{ Potocyrpididae* } \\
\hline Proponcypris cf. levis & 0.29 & 0.04 & 0 & 0 & $0.01 \pm 0.02$ & 0 & 0 & 0 & 0 \\
\hline Proponcypris sp.1 & 0 & 0 & 0.13 & 0 & $0.04 \pm 0.07$ & 0 & 0 & 0 & 0 \\
\hline Proponcypris sp.2 & 0 & 0 & 0.13 & 0 & $0.04 \pm 0.07$ & 0 & 0 & 0 & 0 \\
\hline Chelicerata (Total) & 1.46 & 0 & 0 & 0 & 0 & 0 & 0 & 0 & 0 \\
\hline Unid. familly Acarina* & 1.46 & 0 & 0 & 0 & 0 & 0 & 0 & 0 & 0 \\
\hline$\%$ meiofauna / Total fauna ${ }^{\star *}$ & 64.8 & 95.4 & 93.3 & 98.3 & $95.7 \pm 2.5$ & 42.7 & 42.2 & 17.7 & $34.2 \pm 14.3$ \\
\hline $\begin{array}{l}\text { Total abundances } \\
\text { (number of individuals) }\end{array}$ & 343 & 2696 & 797 & 1274 & $1589 \pm 988$ & 606 & 626 & 20 & $417 \pm 344$ \\
\hline
\end{tabular}


Table 5

Biological descriptors of the three sampled microhabitats in the Marmara Sea. The numbers equivalents of Shannon and Simpson indices are given in italics. The highest values are highlighted in bold. Meiofaunal data is presented notwithstanding the incomplete sampling protocol.

\begin{tabular}{|c|c|c|c|}
\hline Biological descriptors & Bioturbated sediments & Reduced sediments & Carbonate crusts \\
\hline Macrofauna -dominant & $\begin{array}{l}\text { Bivalves and polychaetes, } \\
\text { reaching respectively } 50 \text { and } \\
36 \% \text { of total abundance }\end{array}$ & $\begin{array}{l}\text { Large dominance of polychaetes, } \\
\text { reaching a mean of } 96.1 \% \text { of total } \\
\text { abundance } \\
\text { (Dorvilleidae, Ampharetidae) }\end{array}$ & $\begin{array}{l}\text { Gastropods and bivalves in } \\
\text { various proportions, reaching } \\
\text { a mean of } 54.5 \text { and } 29.4 \% \text { of } \\
\text { total abundance, respectively }\end{array}$ \\
\hline Macrofauna -others & $\begin{array}{l}\text { Gastropods, crustaceans, } \\
\text { aplacophora, chelicerates, } \\
\text { echinoids }\end{array}$ & Bivalves, gastropods & $\begin{array}{l}\text { Cnidarians, polychaetes, } \\
\text { crustaceans }\end{array}$ \\
\hline Macrofaunal densities & $9300 \mathrm{ind} / \mathrm{m}^{2}$ & $3433 \pm 2740 \mathrm{ind} / \mathrm{m}^{2}$ & $15325 \pm 9440 \mathrm{ind} / \mathrm{m}^{2}$ \\
\hline Jaccard's similarity coefficient ${ }^{\mathrm{a}}$ & - & 0.44 & 0.54 \\
\hline Symbiont-bearing fauna & $3.8 \%$ & $0 \%$ & $8.9-68.8 \%$ \\
\hline Mean total biomass $\left(\mathrm{kg} \mathrm{ww} / \mathrm{m}^{2}\right)$ & 0.0018 & $0.0019 \pm 0.001$ & $0.806 \pm 0.25$ \\
\hline \multicolumn{4}{|l|}{ Macrofaunal diversity indices } \\
\hline Richness $(\mathrm{S})^{\mathrm{b}}$ & 21 & 7 & 18 \\
\hline Shannon $\left(H_{e}^{\prime}\right)^{b}$ & 2.42 & 0.77 & 1.37 \\
\hline $\operatorname{Exp}\left(H_{e}^{\prime}\right)$ & 11.25 & 2.16 & 3.94 \\
\hline $\begin{array}{l}\text { Simpson }\left(D_{G S}\right)^{b} \\
\left(1 / 1-D_{G S}\right)\end{array}$ & $\begin{array}{l}0.87 \\
7.73\end{array}$ & $\begin{array}{l}0.43 \\
1.76\end{array}$ & $\begin{array}{l}0.56 \\
2.29\end{array}$ \\
\hline Evenness $\left(\mathrm{J}^{\prime}\right)^{\mathrm{b}}$ & 0.79 & 0.39 & 0.47 \\
\hline Meiofauna -dominant & $\begin{array}{l}\text { Nematodes with } 81 \% \text { of the total } \\
\text { abundance }\end{array}$ & $\begin{array}{l}\text { Nematodes with nearly } 99.9 \% \text { of } \\
\text { the total abundance }\end{array}$ & $\begin{array}{c}\text { Nematodes with } 86.6 \% \text { of the } \\
\text { total abundance }\end{array}$ \\
\hline Meiofauna -others & $\begin{array}{l}\text { Copepods, nauplii, ostracods } \\
\qquad(19 \%)\end{array}$ & Copepods, ostracods (0.1\%) & Copepods (13.4\%) \\
\hline Meiofaunal densities & $16900 \mathrm{ind} / \mathrm{m}^{2}$ & $79450 \pm 49396 \mathrm{ind} / \mathrm{m}^{2}$ & $10424 \pm 8331 \mathrm{ind} / \mathrm{m}^{2}$ \\
\hline Jaccard's similarity coefficient ${ }^{a}$ & - & 0.50 & 0.52 \\
\hline
\end{tabular}

\section{Meiofaunal diversity indices}

\begin{tabular}{cccc}
\hline Total richness $(\mathrm{S})^{\mathrm{b}}$ & $\mathbf{9}$ & 3 & 6 \\
\hline \multicolumn{1}{c}{ Copepoda richness $(\mathrm{S})^{\mathrm{b}}$} & $\mathbf{5}$ & 1 & 5 \\
\hline \multicolumn{1}{c}{ Ostracoda richness $(\mathrm{S})^{\mathrm{b}}$} & $\mathbf{2}$ & 1 & 0 \\
\hline \multicolumn{1}{c}{ Acarina richness $(\mathrm{S})^{\mathrm{b}}$} & $\mathbf{1}$ & 0 & 0 \\
\hline $\begin{array}{l}\text { Shannon }\left(\mathrm{H}_{\mathrm{e}}\right)^{\mathrm{b}} \\
\text { Exp }\left(H_{\mathrm{e}}\right)\end{array}$ & $\mathbf{0 . 7 6}$ & 0.01 & 0.47 \\
\hline $\begin{array}{l}\text { Simpson }\left(\mathrm{D}_{\mathrm{GS}}\right)^{\mathrm{b}} \\
\left(1 / 1-D_{\mathrm{GS}}\right)\end{array}$ & $\mathbf{0 . 1 4}$ & 1.01 & 1.60 \\
\hline Evenness $\left(\mathrm{J}^{\prime}\right)^{\mathrm{b}}$ & $\mathbf{0 . 3 5}$ & 0.002 & 0.22 \\
\hline
\end{tabular}


${ }^{\text {a }}$ Mean Jaccard's similarity coefficient computed without $\mathrm{CC}_{\mathrm{Box}}$,

1285

${ }^{\mathrm{b}}$ Diversity indices are given for macrofaunal and meiofaunal data with $\mathrm{CC}_{\mathrm{Box}}$ included in both case.

1286

1287

1288 
Table 6

Review of the characteristics of different cold seep sites described by different authors, in terms of habitat, dominant fauna and related environmental conditions. This non-exhaustive list was compiled according to the availability of environmental data. SS: soft sediments, Co: concretions, Co/SS: concretions surrounded by soft sediments, GH/SS: gas hydrates within soft sediments.

\begin{tabular}{|c|c|c|c|c|c|c|c|}
\hline Sites & Habitat type & Substratum & Dominant fauna & $\mathrm{O}_{2} \mu \mathrm{mol} / \mathrm{l}$ & $\mathrm{CH}_{4} \mu \mathrm{mol} / \mathrm{l}$ & $\mathrm{SO}_{4}{ }^{2-} \mathrm{mmol} / \mathrm{l}$ & Authors \\
\hline $\begin{array}{l}\text { Gulf of Cadiz } \\
\text { Cap. Arutyunov } \\
\text { MV }\end{array}$ & $\begin{array}{l}\text { Siboglinidae } \\
\text { fields }\end{array}$ & SS & $\begin{array}{l}\text { Siboglinum } \\
\text { poseidoni }\end{array}$ & No data & $0.3-1.1$ & 30 & $\begin{array}{c}\text { Niemann et al., } \\
2006 a ; \\
\text { Sommer et al., } \\
2009 a\end{array}$ \\
\hline \multirow[t]{2}{*}{$\begin{array}{l}\text { Hydrate Ridge } \\
\text { Southern Summit }\end{array}$} & Clam beds & SS & $\begin{array}{c}\text { Calyptogena } \\
\text { pacifica, } \\
\text { C. kilmeri }\end{array}$ & 20 & 0.6 & 28 & $\begin{array}{l}\text { Sahling et al., } \\
\text { 2002; Torres et } \\
\text { al., } 2002\end{array}$ \\
\hline & Microbial mats & $\mathrm{GH} / \mathrm{SS}$ & Beggiatoa sp. & 20 & 1 & 28 & “ \\
\hline \multirow{2}{*}{$\begin{array}{l}\text { Olimpi field - } \\
\text { MedRidge } \\
\text { Napoli MV }\end{array}$} & $\begin{array}{l}\text { Siboglinidae } \\
\text { bushes }\end{array}$ & SS & $\begin{array}{l}\text { Lamellibrachia aff. } \\
\text { anaximandri }\end{array}$ & $202-212$ & 0.35 & 31 & $\begin{array}{l}\text { Ritt et al., in } \\
\text { prep. }\end{array}$ \\
\hline & $\begin{array}{l}\text { Carbonate } \\
\text { crusts }\end{array}$ & Co & $\begin{array}{l}\text { Lurifax vitreus, } \\
\text { Porifera }\end{array}$ & $196-199$ & $2.27-4.29$ & 31 & “ \\
\hline \multirow{2}{*}{$\begin{array}{l}\text { Anaximandre } \\
\text { Mounds } \\
\text { Amsterdam MV }\end{array}$} & $\begin{array}{l}\text { Reduced } \\
\text { sediments }\end{array}$ & SS & $\begin{array}{l}\text { Isorropodon aff. } \\
\text { perplexum }\end{array}$ & $188-192$ & 12.5 & $28-31$ & “ \\
\hline & $\begin{array}{l}\text { Carbonate } \\
\text { crusts }\end{array}$ & Co & $\begin{array}{l}\text { Serpulid } \\
\text { polychaetes }\end{array}$ & $194-202$ & $0.25-0.6$ & 31 & “ \\
\hline $\begin{array}{l}\text { Nile deep-sea fan } \\
\text { Cheops MV }\end{array}$ & $\begin{array}{l}\text { Reduced } \\
\text { sediments }\end{array}$ & SS & $\begin{array}{l}\text { Spionid, hesionid } \\
\text { polychaetes }\end{array}$ & No data & $3.7-7.7$ & No data & “ \\
\hline \multirow[t]{2}{*}{ Eel River Basin } & Clam beds & SS & $\begin{array}{l}\text { Calyptogena } \\
\text { pacifica }\end{array}$ & $25-100$ & 1000 & 6.5 & $\begin{array}{l}\text { Levin et al., } \\
\text { 2003; Orphan } \\
\text { et al., } 2004\end{array}$ \\
\hline & Microbial mats & $\mathrm{GH} / \mathrm{SS}$ & Beggiatoa sp. & $<0.1$ & 6500 & 6.3 & “ \\
\hline $\begin{array}{l}\text { Gulf| of Mexico } \\
\text { Green Canyon }\end{array}$ & Mussel beds & SS & $\begin{array}{l}\text { Bathymodiolus } \\
\text { childressi }\end{array}$ & 129 & 21 & 30 & $\begin{array}{l}\text { Aharon et Fu, } \\
\text { 2003; Bergquist } \\
\text { et al., } 2005\end{array}$ \\
\hline \multirow[t]{2}{*}{$\begin{array}{l}\text { Alaska margin } \\
\text { off Unimak island }\end{array}$} & Clam beds & SS & $\begin{array}{c}\text { Vesicomya } \\
\text { extenta, } \\
\text { V. diagonalis }\end{array}$ & 200 & No data & 28 & $\begin{array}{c}\text { Rathburn et al., } \\
2009\end{array}$ \\
\hline & $\begin{array}{l}\text { Siboglinidae } \\
\text { fields }\end{array}$ & SS & Siphonobrachia sp. & 140 & No data & 28 & “ \\
\hline $\begin{array}{l}\text { New Zealand } \\
\text { margin }\end{array}$ & $\begin{array}{l}\text { Ampharetidae } \\
\text { fields }\end{array}$ & SS & $\begin{array}{l}\text { Ampharetid } \\
\text { polychaetes }\end{array}$ & 197 & 1962 & No data & $\begin{array}{c}\text { Sommer et al., } \\
2009 \mathrm{~b}\end{array}$ \\
\hline \multirow[t]{2}{*}{$\begin{array}{l}\text { Gulf of Guinea } \\
\text { Giant pockmark } \\
\text { Regab }\end{array}$} & $\begin{array}{l}\text { Calyptogena } \\
\text { beds }\end{array}$ & SS & $\begin{array}{l}\text { Calyptogena } \\
\text { regab, } \\
\text { Vesicomya aff. } \\
\text { chuni }\end{array}$ & $211-238$ & $0.4-3.4$ & No data & $\begin{array}{l}\text { Olu-Le Roy et } \\
\text { al., } 2007\end{array}$ \\
\hline & $\begin{array}{l}\text { Mytilidae } \\
\text { Beds }\end{array}$ & SS/Co & $\begin{array}{l}\text { Bathymodiolus aff. } \\
\text { boomerang }\end{array}$ & $230-240$ & $0.7-23.2$ & No data & “ \\
\hline
\end{tabular}




\begin{tabular}{|c|c|c|c|c|c|c|c|}
\hline & $\begin{array}{l}\text { Siboglinidae } \\
\text { fields }\end{array}$ & Co & $\begin{array}{c}\text { Escarpia } \\
\text { southwardae }\end{array}$ & $218-232$ & $0.63-2.43$ & No data & “ \\
\hline \multirow[t]{3}{*}{$\begin{array}{l}\text { Norwegian margin } \\
\text { Håkon Mosby MV }\end{array}$} & $\begin{array}{l}\text { Siboglinidae } \\
\text { fields }\end{array}$ & SS & $\begin{array}{c}\text { Oligobrachia } \\
\text { haakonmosbiensis, } \\
\text { Siboglinum } \\
\text { contortum }\end{array}$ & 270 & 0.7 & 28 & $\begin{array}{c}\text { Niemann et al., } \\
2006 \mathrm{~b}\end{array}$ \\
\hline & Microbial mats & SS & Beggiatoa sp. & 270 & 0.3 & 28 & " \\
\hline & Centre & SS & $\begin{array}{l}\text { Meiofauna } \\
\text { (Copepoda) }\end{array}$ & 270 & 5.7 & 28 & $\begin{array}{l}\text { Niemann et al., } \\
\text { 2006b; Van } \\
\text { Gaever et al., } \\
2006\end{array}$ \\
\hline \multirow[t]{3}{*}{$\begin{array}{l}\text { Nankaï Trench } \\
\text { Off Kumano }\end{array}$} & Clams beds & SS & Calyptogena spp. & No data & 0.006 & 28.3 & $\begin{array}{l}\text { Toki et al., } \\
2004\end{array}$ \\
\hline & Tubeworms & SS & Vestimentiferan? & No Data & $0.006-300$ & 28.2 & “ \\
\hline & Microbial mats & SS & & No Data & $0.2-300$ & 28.5 & “ \\
\hline \multirow[t]{3}{*}{ This study } & $\begin{array}{l}\text { Reduced } \\
\text { sediments }\end{array}$ & SS & $\begin{array}{l}\text { Ampharetid, } \\
\text { dorvilleid } \\
\text { polychaetes }\end{array}$ & $18-51$ & $0.14-0.7$ & $19-26$ & Ritt et al. \\
\hline & $\begin{array}{l}\text { Bioturbated } \\
\text { sediments }\end{array}$ & SS & $\begin{array}{c}\text { Paraonid } \\
\text { polychaetes, } \\
\text { lucinid bivalves }\end{array}$ & No data & No data & 31 & “ \\
\hline & $\begin{array}{l}\text { Carbonate } \\
\text { crusts }\end{array}$ & Co & Idas sp. nov. & No data & No data & No data & “ \\
\hline
\end{tabular}

Resume of the range of chemical concentrations for the different substratum and assemblage types (all studies combined). Higher values are highlighted in bold.

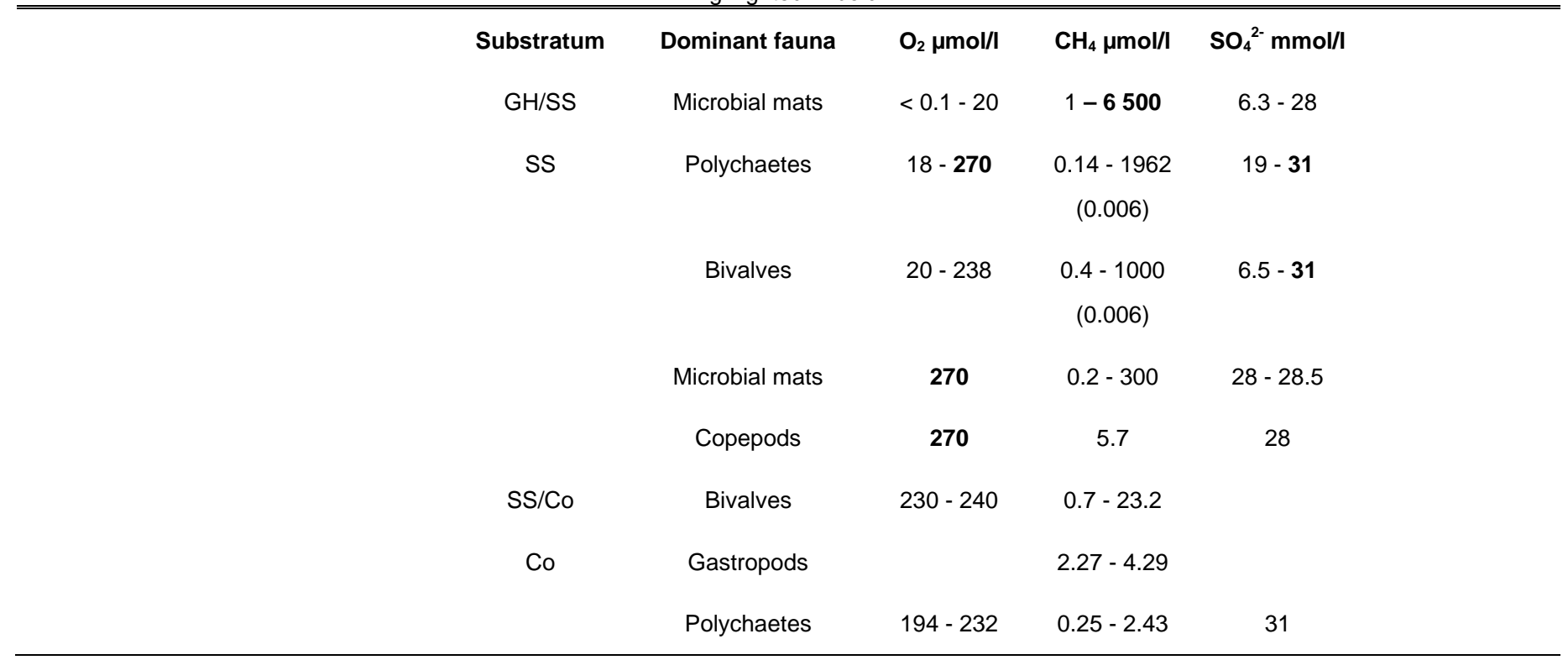

